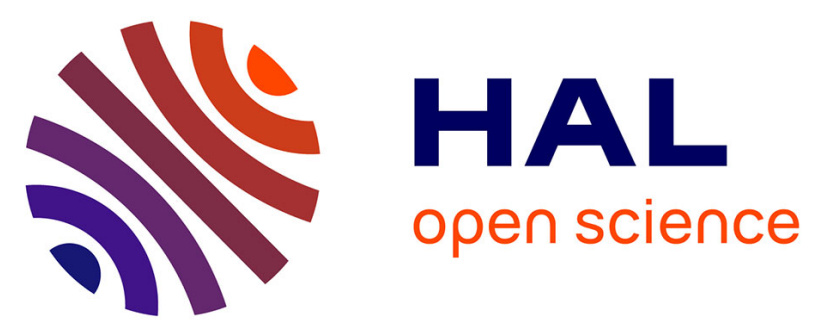

\title{
The evolution of a rural territory at plot scale: Between hyper-fragmentation and land grabbing (irrigation perimeter PC15 - Marianina Valley, Alaotra-Mangoro, Madagascar)
}

Kenji Fujiki, Michel Mietton, Andotiana Andriamasinoro, William

Andriamasinoro

\section{To cite this version:}

Kenji Fujiki, Michel Mietton, Andotiana Andriamasinoro, William Andriamasinoro. The evolution of a rural territory at plot scale: Between hyper-fragmentation and land grabbing (irrigation perimeter PC15 - Marianina Valley, Alaotra-Mangoro, Madagascar). Land Use Policy, 2015, 43, pp.170 - 185. 10.1016/j.landusepol.2014.11.009 . hal-01112801

\section{HAL Id: hal-01112801 \\ https://hal.science/hal-01112801}

Submitted on 26 May 2016

HAL is a multi-disciplinary open access archive for the deposit and dissemination of scientific research documents, whether they are published or not. The documents may come from teaching and research institutions in France or abroad, or from public or private research centers.
L'archive ouverte pluridisciplinaire HAL, est destinée au dépôt et à la diffusion de documents scientifiques de niveau recherche, publiés ou non, émanant des établissements d'enseignement et de recherche français ou étrangers, des laboratoires publics ou privés.

\section{(ㅇ)(1) $\$$}

Distributed under a Creative Commons Attribution - NonCommercial - NoDerivatives 44.0 


\title{
The evolution of a rural territory at plot scale: between
} hyper-fragmentation and land grabbing (irrigation perimeter PC15 - Marianina Valley, Alaotra-Mangoro, Madagascar)

\author{
Kenji Fujiki ${ }^{*}$, Michel Mietton $^{a}$, Andotiana Andriamasinoro $^{b}$, William Andriamasinoro $^{c}$ \\ ${ }^{a}$ Université Lyon 3 J. Moulin CRGA - UMR 5600 EVS CNRS, 18 rue Chevreul, 69007 Lyon (France); \\ b Projet BVLac (Madagascar); ${ }^{\mathrm{c}}$ Andri-Ko (Madagascar)
}

\begin{abstract}
The 'territory' concept is addressed at a scale rarely envisaged - that of the plot through the study of a large rice irrigation perimeter in the heart of the Lake Alaotra region in Madagascar. The methodology followed in this study relies on the processing of landholding inventories. These inventories are remarquable, first for their quality, as they are at the same time quantitative and mapped (GIS-based inventories). They also allow longterm trend analyses inasmuch as they take place for a long period of time, from 1970 to 2012. Results of this study consist in two different conclusions: first, an obvious trend for the fragmentation (division) of plots and the decrease in the size of holdings is identified, though this fragmentation is not equal everywhere. These results confirm the general trend observed in lake Alaotra region and in Madagascar regarding land pressure and fragmentation due to demographic and other socio-cultural factors. Second, fragmentation dynamics hides other less perceptible landholding phenomena. Specifically, it masks land grabbing by new and enterprising rice growers who increase their holdings by profiting from the problems experienced by the smallest farm owners whose fragmented land is no longer viable.
\end{abstract}

\section{Keywords}

Madagascar; Lake Alaotra region; Irrigated system; Plot dynamics; Land fragmentation; Land grabbing; GIS analysis 


\section{Introduction}

'Territory' has now become a key concept in geography and space planning. Though it may appear as a polysemous if not a blanket term, territory is generally defined as a socially demarcated, appropriated space that is marked by the play of stakeholders and authorities at all scales (Moine, 2006; Sack, 1997). Specifically, a territory is indissociable from the question of land, as land consists in a finite resource which is appropriated and subject to competition (Elden, 2010). The distribution of land, the pressure bearing on it and plot division are closely affected by returns on production, by land use and by population pressure (Chaléard and Mesclier, 2010).

However, it is rare to address a territory at a smaller scale, that of the plot, and this is the scale used here. Focus is on a large irrigated rice production system, Perimeter PC15 Marianina Valley, that forms part of the large Malagasy 'rice granary', the Lake Alaotra basin (Raunet, 1984) (Figure 1). The perimeter seems basically ambivalent. Although it is presented as the most efficient perimeter in the region for both water control and paddy rice yields (average 4 t/ha) (Devèze et al., 2003), a number of questions have been raised with regard to the sustainability of the irrigation system (Belloncle et al., 2002; Fujiki, 2013; Fujiki et al., 2014). The supposed efficiency of the irrigation network contributes to the attractiveness of the perimeter and further accentuates the already high population and landholding pressure throughout the region (Garin, 1998). This ambivalence echoes the international context marked by the calling into question of large hydraulic projects, with these being accused of wasting water (Perry et al., 2009), causing various ecological constraints and finally representing substantial economic costs (Jamin et al., 2011; Turral et al., 2010).

The research problematics addressed here are based on identifying and explaining the landholding dynamics of the perimeter and the territorial strategies used by rice growers in the area covered by the irrigation network. A twin hypothesis is put forward: first, in largescale quantitative analysis the hyper-fragmentation of land is significant throughout the perimeter, forming the ultra-dominant dynamics; second, more detailed local analysis reveals very varied and divergent territorial strategies from the abandoning of non-viable 
plots by farmer-legatees to the systematic purchase of land by newly arrived persons and some of the largest landowners.

It is easy to explain the interest of the subject and two reasons can be put forward. First, the scale of the plot is the scale of the lives of farmers, the users of the irrigation system. The 'territory' concept has its full significance at this scale as the latter forms the real foundation of development of the perimeter and, beyond this, the drainage basin. Interventions by the state, by the manager of the perimeter and by donors concerning the management of the irrigation and drainage system are made in an extremely complex land tenure framework in which common law and modern law (Droy, 1994; Evers et al., 2006), and consolidated and allocated lands (Bouderbala et al., 1992) are mingled. This framework features a very dense, changing field layout that forms the base for relations and also efforts to get the upper hand between owner users and developers. The plot pattern is also the basis for relations between persons in the context of an agrarian society marked by the power of land. Land forms economic power (today, rice fields are often still the main source of household income) (Carimentrand, 2011), symbolic power (rice is still a crop that bears prestige and is central to Malagasy identity and myths), a heritage (farmers aim at passing on their land-intact or enlarged-to their children) (Funel et al., 1985) and political power (the plot layout is the basis for client relations between managers/large landowners and clients/tenant farmers) (Blanc-Pamard, 1987).

Secondly, in the face of landholding pressure that is particularly strong for irrigated land in sub-Saharan Africa, with the increase in micro-plots (Blanc-Pamard and Cambrézy, 1995; Bouderbala et al., 1992), the literature has been focused above all on the interest of landholding security and the role of property and tenure on agricultural intensification (Bellemare, 2013; De Janvry et al., 2001; Lavigne Delville, 1998; Le Roy et al., 1996). Land fragmentation is relatively left aside and often reduced to just one factor among others in agricultural productivity. It is essential here to note that a specific definition of land fragmentation has been retained for this paper. In our study area, land consolidation occurred in the late 1960s, and land 'lots' were attributed to each farmer, according to the following principle: for each lot, a single owner-operator, a single holding (holding is understood in this paper as land ownership) and a single hydraulic unit. This principle did not stand for long: indeed, those lots were then divided into plots over the years: this is what is 
meant here by land fragmentation. Many authors define land fragmentation as the division of holdings into several plots that are dispersed over a large area but farmed as single units (King and Burton, 1982; Manjunatha et al., 2013; Niroula and Thapa, 2005). In this paper, land fragmentation should hence on the contrary be understood as the simple division of lots into plots over time (plots with possibly different owners). Nonetheless, if a same lot may today be divided into several plots, some holdings may extend in the same way over several lots, as some rich owners do not hesitate to buy scattered plots over the perimeter. Here, stress is laid on a detailed, mapped study of fragmentation in order to observe the precise implications of the phenomenon on the management of a perimeter from both the socio-institutional and hydraulic angles.

A description of the historico-geographic context of the perimeter is followed by details of the methodology and then the results of the research. 


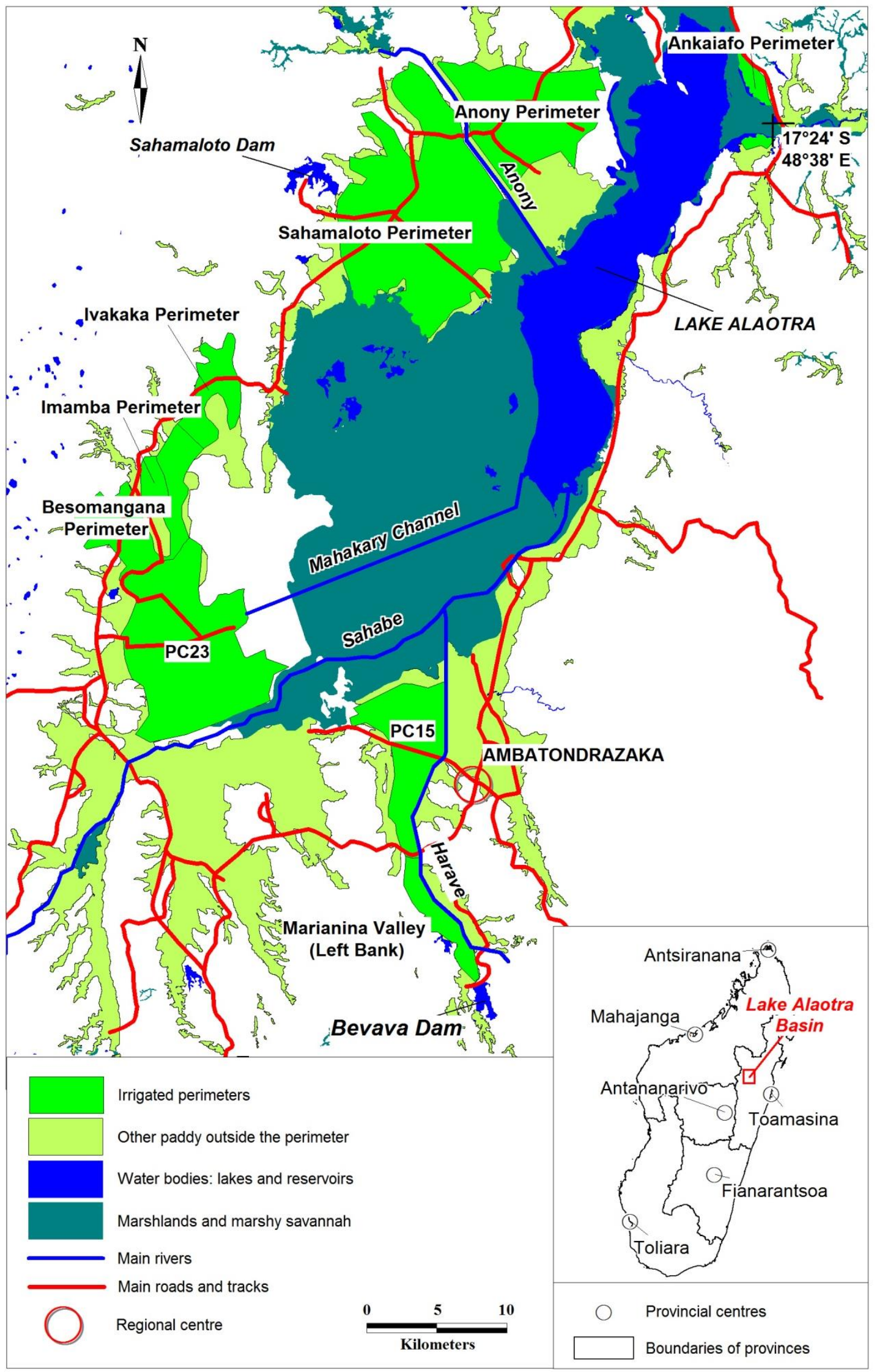

Figure 1. The Lake Alaotra basin (Data: BVLac). 


\section{The context}

The Lake Alaotra region became Madagascar's large rice production centre in the twentieth century and now accounts for $1 / 8$ of national production (Carimentrand, 2011). However, the history of land development operations illustrates the partial failure of the policies applied in the region.

\subsection{Lake Alaotra region: Madagascar's large rice granary}

The Lake Alaotra basin is in the Malagasy highlands. The tropical humid climate is tempered by altitude (average inter-annual precipitation 1000 to $1250 \mathrm{~mm}, 90 \%$ of which is from November to March)(Garin, 1998; Teyssier, 1994). The region is remarkable for both the environment and its rice production. The basin benefits from protection of the wetlands by virtue of the Ramsar Convention. The largest lake in the country with an area of $456 \mathrm{~km}^{2}$ at an elevation of $751.20 \mathrm{~m}$, Lake Alaotra is surrounded by marshland $\left(320 \mathrm{~km}^{2}\right)$ and marshy savannah $\left(210 \mathrm{~km}^{2}\right)$ (Ferry et al., 2009). The plains around the lake basin $\left(820 \mathrm{~km}^{2}\right)$ and in some twenty adjacent valleys laid out like spokes around the plains are used mainly for paddy rice (Figure 1).

The region gained its status of rice granary little by little during the twentieth century, first with impetus from the French colonial administration with, in particular, the implementation of various modern hydro-agricultural facilities (main canals, drains, diversion intakes and storage dams) in the 1950s, following "Operation Lake Alaotra » (Garin, 1998). After independence in 1960, a rural development area (Aire de Mise en Valeur Rurale, AMVR) was set up at the site of the large development operations that had been completed. It was supervised by SOMALAC (Société d'Aménagement Malgache du Lac Alaotra) from 1961 onwards. Most of the large irrigation perimeters shown in figure 1 are the direct inheritors of the AMVR. In contrast, the other rice areas were not managed by the SOMALAC but were supervised loosely by the Rural Engineering administration (Génie rural) (Bouderbala et al., 1992). Little development was done and they have conserved their 'traditional' character. The SOMALAC had three key tasks in the AMVR: the intensification of rice growing, land consolidation and finishing touches to the hydro-agricultural projects started during the colonial period (Lapierre, 1964; Société Centrale pour l'Equipement du 
Territoire, 1965). Although the SOMALAC's position, and hence that of the state, was central to the management of the large irrigated perimeters and the rice sector, difficulties increased after 1972 and continued until 1982 in the twin context of a socialist revolution and the disorganisation of the administration, with the degradation of hydro-agricultural infrastructure and the development of a black market running parallel to the state monopoly instituted for rice at Lake Alaotra in 1971 (Droy, 1998; Rakoto Ramiarantsoa, 1985). In the mid-1980s, within the framework of rehabilitation projects under the aegis of the World Bank (Banque mondiale, 1992) and in the context of an international trend aimed at state withdrawal in the management of large water facilities (Garces-Restrepo et al., 2007; Turral, 1995; Turral et al., 2010), the rice sector was liberalised (in 1986 in the region of the lake), and perimeter management was decentralised and entrusted to Water Users Associations (Associations d'Usagers de l'Eau, AUE), first gradually and then rapidly after the closing down of the SOMALAC in 1991 (Direction du Développement et de la Coopération Technique, 2000). Both institutional and hydraulic management are still very difficult today as the Water Users Associations have neither the technical skills nor the financial resources of the SOMALAC, in spite of active support from donors (JICA, 2008).

From this point of view, the PC15- Marianina Valley stands out from the other large perimeters in the region by virtue of its mastery of water and high yields (at least in relative terms). There are two reasons for this. First; it is one of only two perimeters supplied by a storage dam-Bevava dam - that gives it comparatively good assurance of its water (Figure 2). Second, the perimeter has received particularly close attention from donors with regard to the rehabilitation of infrastructure and technico-financial assistance for the AEUs (funding from Agence Française de Développement since 1997 and then the BVLac project from 2003) (Broutin et al., 2011). The perimeter has an area of 4000 hectares and is divided into two ensembles. Upstream, the left bank of the Marianina Valley (1100 ha) was incorporated in the irrigation network at a late date: it was only connected to supply from the Bevava in 1993 when the Main Left Bank Canal (Canal Principal de Rive Gauche - CPRG) was built. Historically, the valley is outside the SOMALAC intervention zone and is thus still marked today by traditional development works (non-hierarchic irrigation networks, canals dug by the farmers). Downstream, PC15 occupies 3000 ha in one of the large plains around the lake; it was the pride of the old SOMALAC, with relatively modern hydro-agricultural 
developments and regular, hierarchic water distribution. Each secondary canal thus feeds a hydraulic grid and each tertiary canal feeds a lot (BRL-Madagascar, 2008). The nomenclature used in the study to refer to the various components of the perimeter are summarised in Table 1: each ensemble (PC15 and the Marianina Valley) is divided into hydraulic sectors, each of which includes several users associations; in PC15, each association covers several hydraulic grids.

\begin{tabular}{|c|c|c|c|}
\hline ENSEMBLE & SECTOR & AUE & $\begin{array}{c}\text { IRRIGABLE AREA IN } 2009 \\
\text { (ha) }\end{array}$ \\
\hline \multirow{5}{*}{$\begin{array}{l}\text { Marianina } \\
\text { Valley }\end{array}$} & \multirow{2}{*}{ CPRG Upstream } & Ambolotara & 333 \\
\hline & & Bemanjato & 160 \\
\hline & \multirow{3}{*}{$\begin{array}{c}\text { CPRG } \\
\text { Downstream }\end{array}$} & Ambohimasina & 329 \\
\hline & & Andranomangatsiaka & 213 \\
\hline & & Ambohibary & 97 \\
\hline \multirow{11}{*}{ PC15 } & \multirow{2}{*}{18 Upstream } & Grids 1-2-3 & 334 \\
\hline & & Grids 4-7-8 & 206 \\
\hline & \multirow{3}{*}{18 Downstream } & Grids 9-14 & 197 \\
\hline & & Grids 15-16 & 287 \\
\hline & & Grid 21 & 234 \\
\hline & \multirow{3}{*}{12 Upstream } & Grids 5-6 & 252 \\
\hline & & Grids $11-12$ & 170 \\
\hline & & Grids $10-13$ & 333 \\
\hline & \multirow{3}{*}{12 Downstream } & Grids $17-18$ & 242 \\
\hline & & Grids $19-20$ & 249 \\
\hline & & Grids $22-23$ & 448 \\
\hline
\end{tabular}

Table 1. Nomenclature of the PC15- Marianina Valley irrigation perimeter (Data: BVLac). 


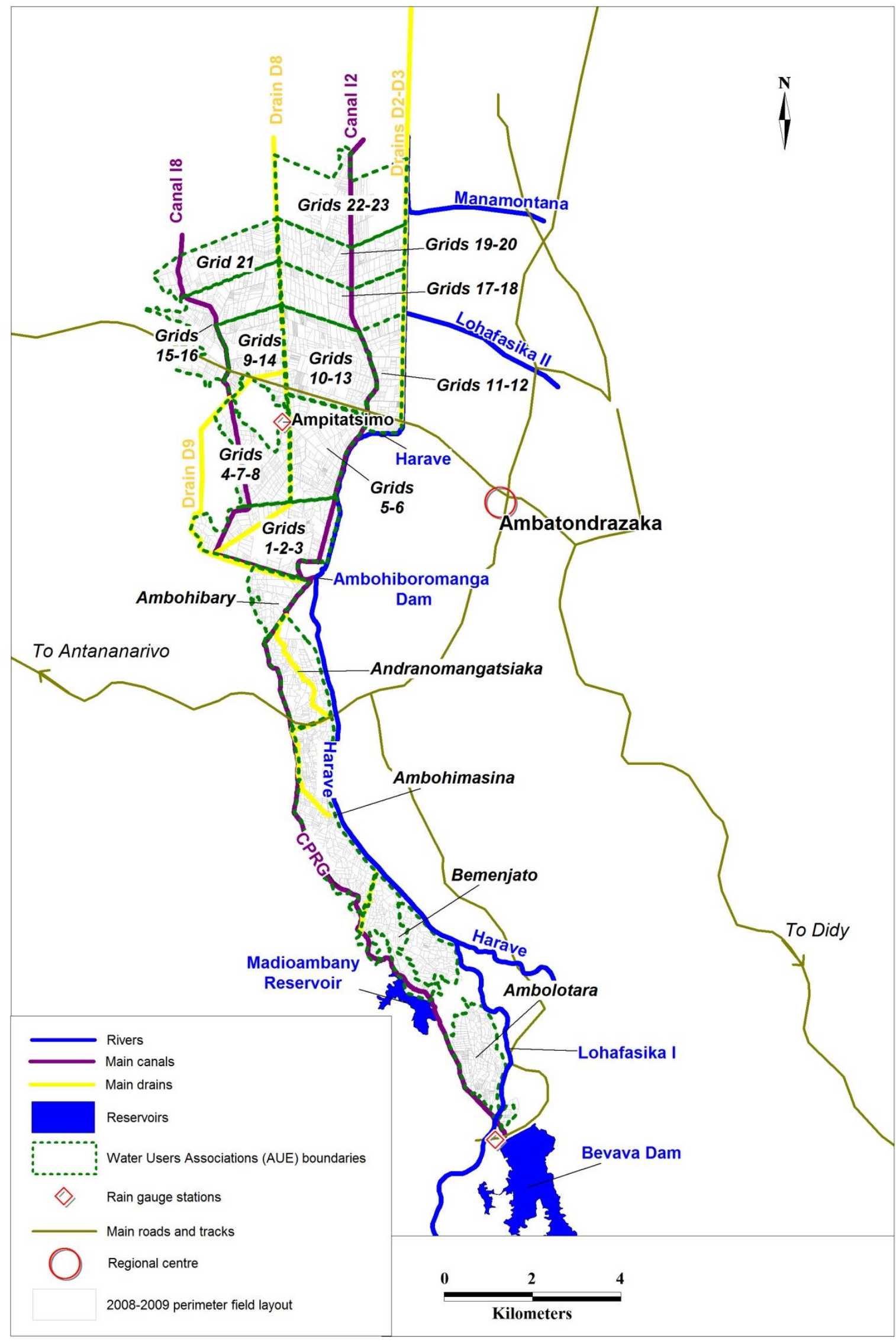

Figure 2. The PC15- Marianina Valley irrigation network (Data: BVLac). 


\subsection{The regional history of land development operations: failures and impacts.}

The landholding history of Lake Alaotra and in particular that of the perimeter PC15Marianina Valley shows the failure of the landholding developments undertaken and, beyond this, of the regional development policies that supported them. The French colonial administration aimed at establishing the region as a rice granary favouring a colonial operation model. For this, the engineer Longuefosse delineated Réserves Indigènes (RI) and Périmètres de Colonisation (PC) around the lake between 1915 and 1925. The 43 RIs were mainly in the valleys adjacent to the lake and were areas already used by and reserved for the Madagascans (Marianina Valley became RI 11). In contrast, the 40 PCs around the lake were in plains remaining to be cleared and were a priori for European colonists (Garin, 1998).

After independence, the government of Madagascar promoted a family farm model, specifically in the lake region. The model, created from nothing, aimed at fostering the emergence of social development suitable for the intensification of rice growing. It consisted of a standard farm under owner occupancy with 5 workers cultivating 5 ha of rice with yields in excess of $3 \mathrm{t} /$ ha (Teyssier, 1994). This model was used within the framework of land consolidation implemented by the SOMALAC within the limits of the AMVR (Rural Development Area). The latter includes the PCs (renamed Périmètres de Culture) that had benefited from hydro-agricultural development works, including PC15. In contrast, no land redevelopment was performed in the old RIs like the Marianina Valley and that were outside the AMVR. Redevelopment was performed in two stages in the mid-1960s. Within the AMVR, the land belonging to owners already settled, with a paper title or common law ownership, was consolidated, mainly by compulsory purchase. In exchange, the owners received a lot of between 5 and 20 ha according to the size of their former holding and their former income (consolidated land). The remaining area was distributed as 3 to 5 -ha lots to landless farmers (allocated land) (Bouderbala et al., 1992; Erismann, 2014; Garin, 1998; Louzoun, 1967). After land consolidation and allocation, non owner farming was forbidden by SOMALAC regulations and by the law-share-cropping became illegal in 1975 (Droy, 1998). Similarly, the division and sale of lots were forbidden. There must be just one owneroperator for each lot. However, it can be seen that the model has weakened. Today, lots have been divided into numerous plots and indirect farming has never disappeared from the 
perimeters. As an example, the upstream part of PC15 is shown in figure 3 with the many changes in plot layout in the perimeter over the last 50 years.
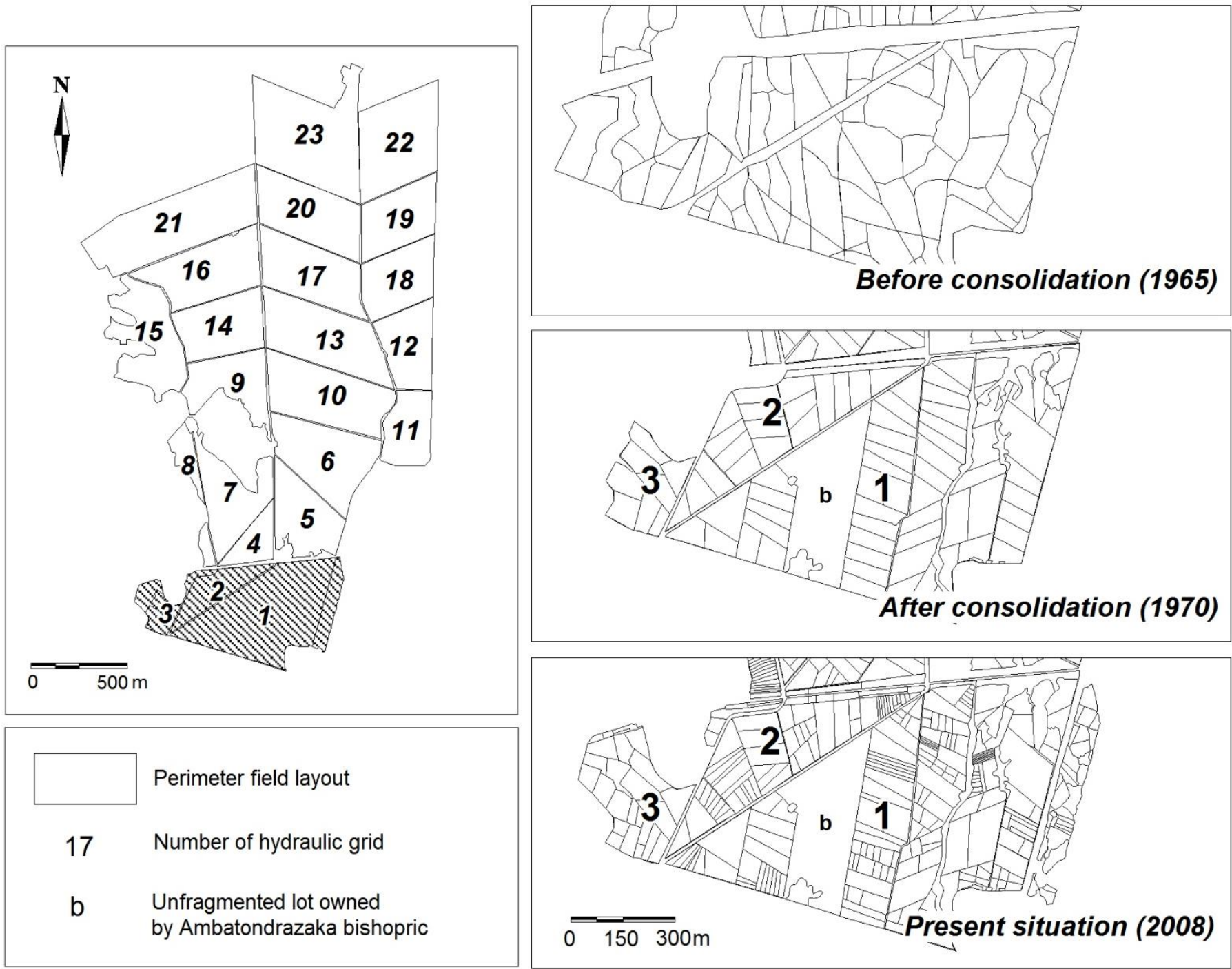

Figure 3. Changes in plot layout in the upstream grids of PC15 (Data: BVLac and SCET).

\section{Methodology}

In addition to bibliographical material, research was based mainly on the gathering and processing of the plot inventories for perimeter PC15 (Marianina Valley) to show the present state and historical dynamics of the plot layout. 


\subsection{The processing of the plot inventories available from 1970 to 2012}

These inventories were drawn up at the end of each cropping season by rice extension officers working in the perimeter and corrected by the chief agricultural technician on behalf of the federation grouping the 16 AUEs in the perimeter (Fédération des Associations des Usagers du Réseau - FAUR). The inventories show the characteristics of each plot: its number, the number of the lot to which it belongs, the total area in hectares and the area subject to charges for the next season (the two are different if a problem is observed), the names and addresses of the owner and the operator. An inventory is available for PC15 alone for the 1970 season. This was 'year zero' for the perimeter and immediately followed land consolidation. An older inventory (1965) also exists but has not been analysed statistically as it is incomplete and is used only as a spatial reference in figure 3 to illustrate the pre-consolidation situation. An inventory has been drawn up each year from 2000 onwards for PC15 and the left bank of Marianina Valley ${ }^{1}$. A supplementary inventory is available for 2012 only for the southern half of PC23, the largest perimeter in the region (9200 ha), south-west of the lake (JICA, 2008; SOGREAH and SOMEAH, 1985). Geographic comparison means that this inventory sheds light on the specific character of the PC15-Marianina Valley perimeter. The five seasons 1970, 2000, 2003, 2008 and 2012 were examined; the others were rejected for reasons of shortage of data. The inventories for 2000, 2003 and 2012 consist of declarations only, so that plot area is estimated but not mapped. In contrast, the plot inventory for the two other seasons (1970 and 2008) was spatialised and plotted in a vector layer (GIS).

\subsection{A global and local analysis of holding and plot trends in the PC15-Marianina Valley perimeter}

The inventories were processed for two purposes. First, this was a diachronic and synchronic study of plots in the PC15- Marianina Valley perimeter aimed on the one hand at revealing landholding dynamics in the long term (1970 to 2012) and the short term (from 2000 onwards) and on the other at examining spatial disparities between the two ensembles (PC15 and Marianina Valley) and, within each ensemble, between the AUEs and the hydraulic grids. Analysis is quantitative and summarises average plot area, holding size and

\footnotetext{
${ }^{1}$ For reasons of convenience, the left bank of the Marianina Valley is henceforth referred to as the Marianina Valley.
} 
the type of tenure and origin of the owners. It was conducted at hydraulic grid scale for PC15 and at AUE scale for Marianina Valley². Results were then analyzed in the light of demographic and land data available on a national scale and issued by the Malagasy Ministry of Agriculture (Ministère de l'Agriculture, de l'Elevage et de la Pêche, 2007) and by the Malagasy censor institute INSTAT (INSTAT, 2013). Though these data presented some imprecisions, they allowed interpreting the results of this study in the context of land dynamics observed more generally, in Alaotra-Mangoro region and in Madagascar.

This general analysis was then overlaid by a detailed study of grid 21. First; analysis of landholding history was conducted for the ten largest (in area) landowners in PC15 that are now sited in grid $21^{3}$. Second, a typology of agrarian evolution of the lots was drawn up for the grid. Grid 21 is particularly suitable for this. It displays a broad range of landholding situations and is also rich in terms of political and sociological issues. It has to handle first recurrent difficulties in institutional management, especially in the collection of charges, and second the strong influence of the inheritors of consolidated land as they are historically against any collective management of irrigation (Ratsimba, 2007). Interpretation of the results is based in particular on previous studies with more qualitative approaches (BlancPamard, 1987; Brochoire, 2009; Garin, 1998; Ratsimba, 2007), but also on interviews of ricecroppers, technicians, and managers of the federation.

\subsection{Methodology limits: the coexistence of legal and customary land law and the difficulty to assess property rights in Madagascar}

Results may finally be misinterpreted if the limits of the inventories are not clearly understood. The latter needed corrections of typing and spelling mistakes (the same name may be spelled in different ways in different inventories but clearly refer to the same person or the same family) in order to follow the histories of the various owners and plots in time. However, due to the very large quantity of information involved, with several thousand plots to cover and describe for each inventory, these corrections could not be systematic except for grid 21.

\footnotetext{
2 'Holdings with areas of less than or more than $\mathrm{x}$ hectares' are a statistic often mentioned in the article. To avoid any confusion, it is noted that this is the sum of holdings registered in the same name in a grid or an AUE and not among grids and AUEs.

${ }^{3}$ This concerns only the ten largest landowners identified as such. Some cannot be included as the various inventories do not necessarily use the same spelling for the same ricegrower in time.
} 
Assessing the property rights in the perimeter remains then the greatest challenge. In Madagascar, land may be owned through customary rights (lex fori) or positive laws (lex loci) (Evers et al., 2013). Official land registration through property titling coexists with customary rights: the latter is based on the belief in the absolute right of the first cultivator of a land and his descendants called 'tompon-tany', masters of the land (Evers, 2005, 2006). Inheritance appears here as the most legitimate mean to keep a land. Moreover, rather than titling a property, or noticing state land administration of a transfer of property (by sale or inheritance), owners prefer using the system of 'petits papiers' (little documents): these are informal land documents 'authenticated' by the stamp of a local authority (Teyssier et al., 2008). Land titling is indeed too long (6 years), too costly, and associated from the point of view of the owners to land taxes. Since 2005, a decentralised landholding security policy made official this system of 'petits papiers', by allowing communes to deliver landholding certificates that are much cheaper and quicker to obtain for the ricegrowers than property titles (Burnod et al., 2012; Rochegude, 2012; Muttenzer, 2010; Teyssier et al., 2009).

Inside the PCs, thanks to the land consolidation led in the 1960 s, land titling is much more widespread than in the rest of the island (Jacoby, 2007): ricegrowers have formal titles in about half of the land, and more than $60 \%$ for the sole PC15, broadly above the national figure ( $7 \%$ of the cultivated area is titled on a national scale). Nonetheless, these titles are generally not up to date, and issuance of titles has been steeply decreasing after the end of SOMALAC (Penot et al., 2014). In the perimeter and sometimes in the very same plots, may then coexist customary, certified and titled properties. The inventories available actually refer to the owners who are identified as such by the technicians of the federation, and expected to pay the water fee. Land titles and certificates are thus not taken into consideration. Due to this difficulty to assess land properties, the inventories cannot be exhaustive: certain owners may not be clearly identified, due to their absence when the censuses are carried out: 'bad payers' in particular are reluctant for their plots (with the water fee due) to be counted. 


\section{Results and Discussion.}

The results of the study are examined in two parts. First, analysis of the general landholding characteristics of the perimeter show the hyper-fragmentation of plots and holdings from 1970 to 2012 and the geographical ambivalence of the perimeter-between PC15, marked by land consolidation, and Marianina Valley, that has inherited the nonegalitarian structures of the Sihanaka regional ethnic groups. Second, the case study devoted to grid 21 provides local details of the general features observed for PC15 as a whole and the drafting of a preliminary typology of the territorial strategies implemented by the users of the network.

\subsection{General landholding dynamics tending towards the hyper-fragmentation of plots}

After a preliminary geographic comparison of the various ensembles studied (PC15, Marianina Valley and PC23), examination of the dynamics of the hyper-fragmentation of PC15 was followed by investigation of social inequality with regard to access to land in the perimeter. Finally, causes of land fragmentation were identified with regard to the landholding and demographic trends observed on a regional and national scale.

\subsubsection{Synchronic geographic analysis: general features of plot layout in 2012.}

The general landholding features of each ensemble in 2012 are shown in Table 2. This shows the specific nature of perimeter PC15-Marianina Valley at the regional scale in comparison with PC23 and the ambivalence of the perimeter between upstream (Marianina Valley or M. V.) and downstream (PC15). 


\begin{tabular}{|c|c|c|c|c|c|c|c|c|}
\hline & \multirow{2}{*}{ Plot layout } & \multirow{2}{*}{$\begin{array}{l}\text { Owner-occupied } \\
\text { plots (\% of the } \\
\text { total) }\end{array}$} & \multirow{2}{*}{$\begin{array}{l}\text { Average plot size } \\
\text { (ha) }\end{array}$} & \multicolumn{5}{|c|}{ Percentages of total plots whose sizes are as follows or less: } \\
\hline & & & & 0.25 ha & 0.5 ha & 1 ha & 3 ha & 5 ha \\
\hline \multirow{3}{*}{ PC23 } & Average & $72,1 \%$ & 2,58 & - & $10,0 \%$ & $35,1 \%$ & $81,0 \%$ & $96,1 \%$ \\
\hline & Maximum for a grid & $94,4 \%$ & 3,51 & - & $37,0 \%$ & $60,0 \%$ & $98,2 \%$ & $100,0 \%$ \\
\hline & Minimum for a grid & $54,8 \%$ & 1,26 & - & $0,0 \%$ & $5,3 \%$ & $57,8 \%$ & $78,9 \%$ \\
\hline \multirow{3}{*}{ PC15 } & Average & $62,8 \%$ & 0,90 & $21,4 \%$ & $51,9 \%$ & $79,1 \%$ & $98,0 \%$ & $99,6 \%$ \\
\hline & Maximum for a grid & $88,4 \%$ & 1,26 & $36,0 \%$ & $72,0 \%$ & $96,0 \%$ & $100,0 \%$ & $100,0 \%$ \\
\hline & Minimum for a grid & $36,8 \%$ & 0,56 & $8,7 \%$ & $36,1 \%$ & $63,9 \%$ & $91,9 \%$ & $98,1 \%$ \\
\hline \multirow{3}{*}{ M.V. } & Average & $58,6 \%$ & 0,69 & $29,3 \%$ & $55,1 \%$ & $80,9 \%$ & $98,7 \%$ & $99,5 \%$ \\
\hline & Maximum for an $A U E$ & $69,6 \%$ & 1,01 & $40,3 \%$ & $65,3 \%$ & $87,2 \%$ & $99,2 \%$ & $100,0 \%$ \\
\hline & Minimum for an $A U E$ & $28,5 \%$ & 0,53 & $8,1 \%$ & $30,1 \%$ & $66,7 \%$ & $95,3 \%$ & $98,7 \%$ \\
\hline \multirow{2}{*}{\multicolumn{3}{|c|}{ Holding size }} & \multicolumn{3}{|c|}{$\begin{array}{l}\text { Percentages of the areas of holdings as } \\
\text { follows or larger: }\end{array}$} & \multicolumn{3}{|c|}{$\begin{array}{l}\text { Percentages of the areas of holdings as } \\
\text { follows or smaller: }\end{array}$} \\
\hline & & & 3 ha & 5 ha & 10 ha & 0,25 ha & 0,5 ha & 1 ha \\
\hline \multirow{3}{*}{ PC23 } & \multicolumn{2}{|c|}{ Average } & $66.3 \%$ & $37.0 \%$ & $11.0 \%$ & - & $1.3 \%$ & $9.2 \%$ \\
\hline & \multicolumn{2}{|c|}{ Maximum for a grid } & - & $60.4 \%$ & $49.9 \%$ & - & $8.6 \%$ & $21.0 \%$ \\
\hline & \multicolumn{2}{|c|}{ Minimum for a grid } & - & $0.0 \%$ & $0.0 \%$ & - & $0.0 \%$ & $1.5 \%$ \\
\hline \multirow{3}{*}{ PC15 } & \multicolumn{2}{|c|}{ Average } & $37.7 \%$ & $9.0 \%$ & $2.5 \%$ & $3.4 \%$ & $14.1 \%$ & $33.8 \%$ \\
\hline & \multicolumn{2}{|c|}{ Maximum for a grid } & $56.2 \%$ & $24.1 \%$ & $13.9 \%$ & $7.9 \%$ & $30.9 \%$ & $62.7 \%$ \\
\hline & \multicolumn{2}{|c|}{ Minimum for a grid } & $0.0 \%$ & $0.0 \%$ & $0.0 \%$ & $0.7 \%$ & $6.4 \%$ & $17.2 \%$ \\
\hline \multirow{3}{*}{ M.V. } & \multicolumn{2}{|c|}{ Average } & $31.9 \%$ & $22.2 \%$ & $11.4 \%$ & $3.4 \%$ & $12.5 \%$ & $30.6 \%$ \\
\hline & \multicolumn{2}{|c|}{ Maximum for an $A U E$} & $71.4 \%$ & $65.4 \%$ & $61.4 \%$ & $5.4 \%$ & $16.5 \%$ & $40.1 \%$ \\
\hline & \multicolumn{2}{|c|}{ Minimum for an $A U E$} & $18.1 \%$ & $3.4 \%$ & $0.0 \%$ & $0.3 \%$ & $3.3 \%$ & $13.4 \%$ \\
\hline
\end{tabular}

Table 2. Synchronic comparison of landholding in perimeters PC23 and PC15- Marianina Valley in 2012 (Data: FAUR and JICA).

First of all, PC23 is clearly different to PC15-Marianina Valley. It is markedly fragmented with average plot size of 2.58 ha per plot with only just $35 \%$ of plots of 1 ha or less. It also has many large holdings (holdings of 5 ha account for more than a third of the total area) and very few small holdings ( $9 \%$ of the area consists of holdings of 1 ha or less). Rice growers consider PC23 to be fairly unattractive for reasons of poor water management and extremely low yields. These features save the perimeter from fragmentation and account for the maintaining of a significant number of large and medium-sized holdings. 
In contrast, PC15 is both fragmented-average plot size 0.9 ha and half of the plots being 0.5 ha or less-and marked by the small number of large holdings ( $9 \%$ of the area of PC15 is accounted for by holdings with an area of 5 ha or more in comparison with a third of the total consisting of holdings of 1 ha and less) because of very strong pressure on landholding.

Finally, Marianina Valley is both very strongly fragmented (average plot size 0.7 ha) and displays considerable differences in holdings. The valley has both numerous small holdings (a third of the area is accounted for by holdings of 1 ha or less) and powerful large holdings (holdings of 10 ha or more account for $11 \%$ of the area of the valley and those of 5 ha account for 22\%). The reason is Marianina Valley's former status of Réserve Indigène, which involves two considerations. First, it was a reserve and concessions (property titles) were awarded during the colonial period. Although the European concessions were nationalised and redistributed in 1973, those awarded to Madagascans remained intact. Second, the reserves were peopled to a considerably extent by Sihanakas or former Merina migrants integrated in Sihanaka society, whereas the new migrants tended to settle in the PCs (Garin, 1998); however, Sihanaka social structure is very divided, ranging from large landholders who use landless sharecropper and small landholders scattered over the very fragmented plot layout.

\subsubsection{The failure of the family farm model and landholding convergence between PC15 and Marianina Valley: non-owner occupancy and hyper-fragmentation}

Despite land consolidation, PC15 experienced an exponential growth of the number of farmers, resulting in two features: hyper-fragmentation and the development of nonowner occupancy. Due to the failure of the family farming model promoted by the SOMALAC, PC15 have become relatively similar to Marianina Valley in its plot structure.

Non-owner occupancy (leasing and share-cropping) was forbidden after land consolidation. However, it appeared suddenly at the end of the 1980s under effect of internal immigration (new arrivals after consolidation found it difficult to acquire land in PC15) and the liberalisation of the economy from 1984-1986 onwards. In 1980-1981, owner occupancy still concerned $80 \%$ of farmers in PC15 villages in comparison with $65 \%$ in Marianina Valley, in 1993 owner occupancy was down to 69\% in PC15 but was still the same 
in Marianina Valley (Garin, 1998). The trend has been stable since then: $37 \%$ of the plots in PC15 are under owner occupancy and 41\% in Marianina Valley. As a comparison, the proportion does not exceed $28 \%$ in PC23 (Table 2), 25\% of lowlands in the lake Alaotra area and $10 \%$ of lowlands on a national scale (Jacoby, 2007). However, two objections can be made to these figures. Firstly, one form of semi-share-cropping involving occasional work carried out by landless share-croppers on holdings belonging to large Sihanaka owners in exchange for cash loans, rice or equipment is too informal and volatile to be taken into account in the inventories (Charmes, 1973, 1975). Secondly, slight variations in occupation status from one year to the next can be seen during the period examined (2000-2012): from $29 \%$ in 2008 and $35-37 \%$ in the other seasons in PC15 and between $36 \%$ and $44 \%$ in Marianina Valley. These variations seem to be correlated partially with fluctuations in paddy production: after a good harvest the owner cultivates his plot himself but not after a mediocre harvest, according to Blanc-Pamard (1987).

Although the development of non-owner occupancy was very sudden in PC15, fragmentation has been an underlying feature: average plot area decreased gradually from some 3.3 ha in 1970 to 1.39 ha in 2000 and 0.90 ha in 2012. The impact of fragmentation is shown on a local scale, in a plot map of grids 1, 2 and 3 in the upstream part of PC15 (Figure 3). At the scale of the whole PC15 (Figure 4), the overall fragmentation coefficient of lots reaches 2.27 , meaning that each lot has been fragmented in average in 2.27 plots. There are nonetheless strong disparities between lots. In the 668 analysed, 19\% have not been fragmented and $18 \%$ have been divided in two in comparison with nearly $60 \%$ that have been fragmented into 3 to 10 plots. 


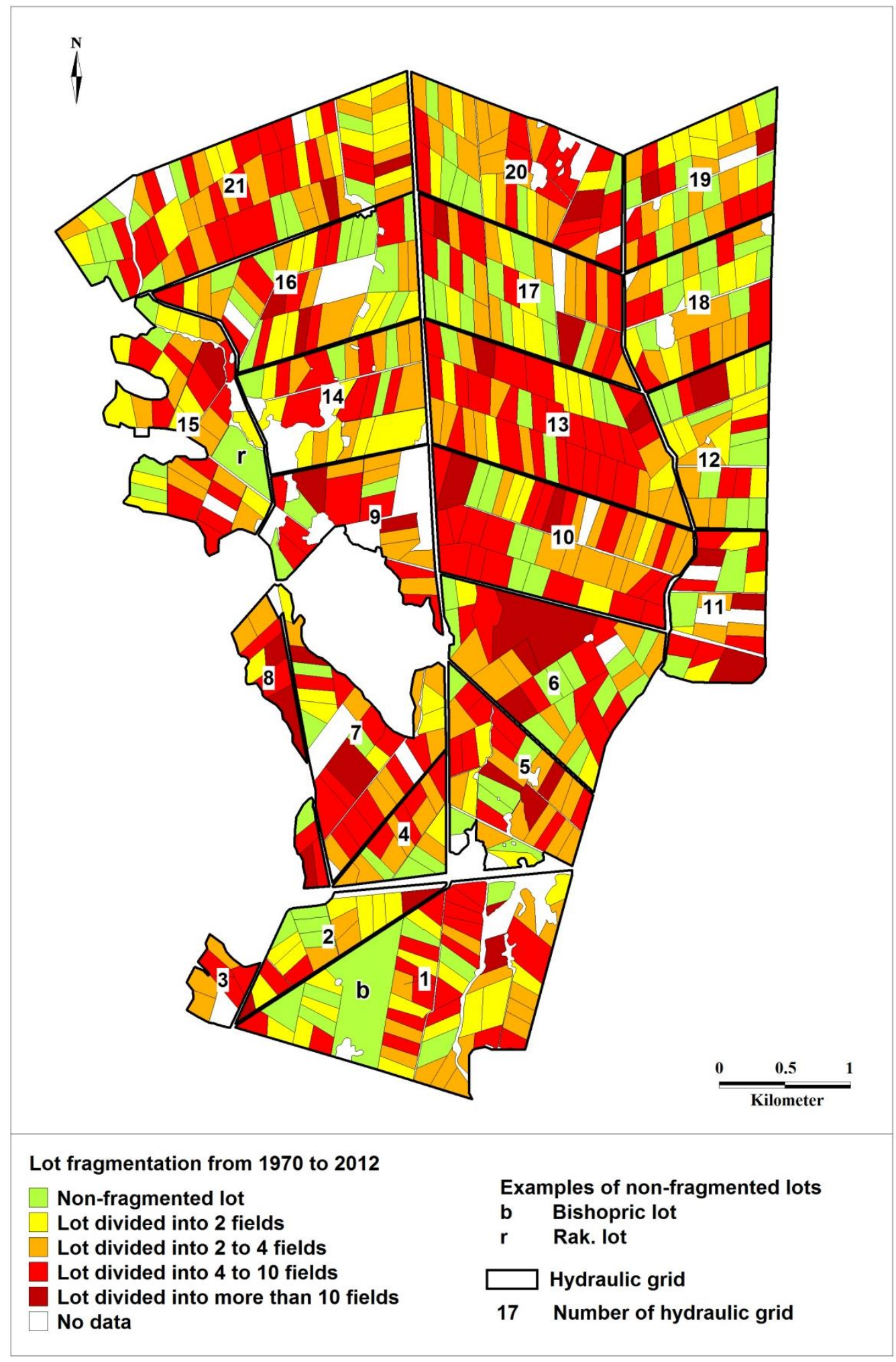

Figure 4. Fragmentation of the original lots in PC15 from 1970 to 2012 (Data: FAUR).

There has been an increasing trend for the formation of micro-plots of 0.5 ha or even 0.25 in the last 12 years (Figure 5). In PC15, plots with an area of 0.5 ha or less already 
formed a third of plot distribution in 2000 and more than half in 2012; 0.25 ha plots were in a clear minority in 2000 and accounted for more than a fifth of plots in 2012. However, strong spatial disparities are seen in figure 6 that shows the situation in 2008. Incidentally, comparison of PC15 with Marianina Valley reveals astonishing dynamics. Fragmentation of plots in the valley was even more sudden than in PC15. In 2000, 0.25 ha plots formed $11 \%$ of the total but flirted with $30 \%$ in 2012 ! The proportion of 0.5 ha plots practically doubled during the same period (from $30 \%$ to 55\%) during the same period. The main areas concerned are the upstream and central parts of the valley: the proportion of 0.25 ha plots is 2.5 times greater at Ambolotara, 5 times greater at Bemanjato and 4 times greater at Ambohimasina. In contrast, the lower part of the valley (especially Andranomangatsiaka) has been spared by hyper-fragmentation. This spatial dichotomy is very clear in figure 7.

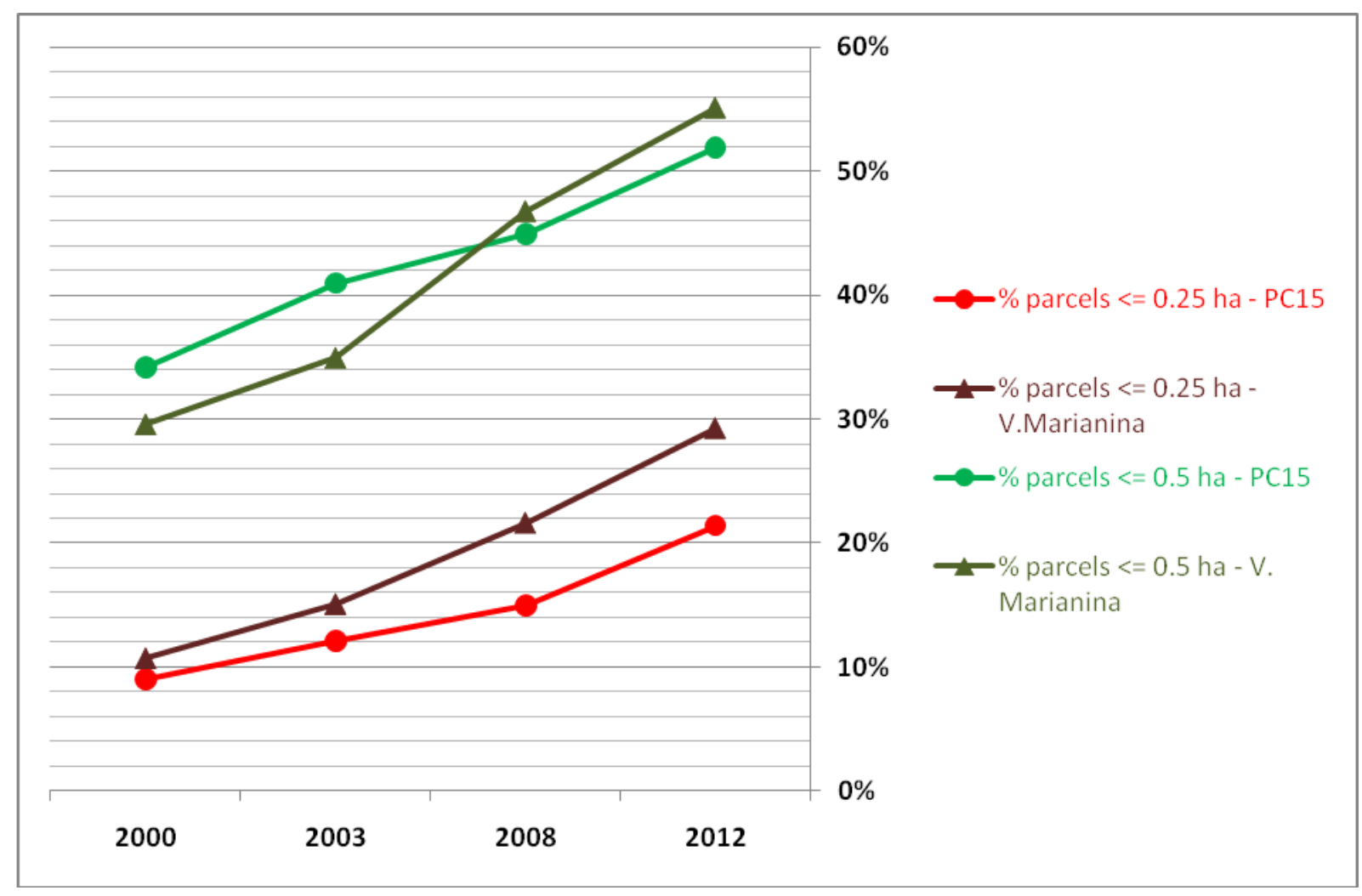

Figure 5. Evolution of the proportion of micro-plots in PC15 and the Marianina Valley from 2000 to 2012 (Data: FAUR). 


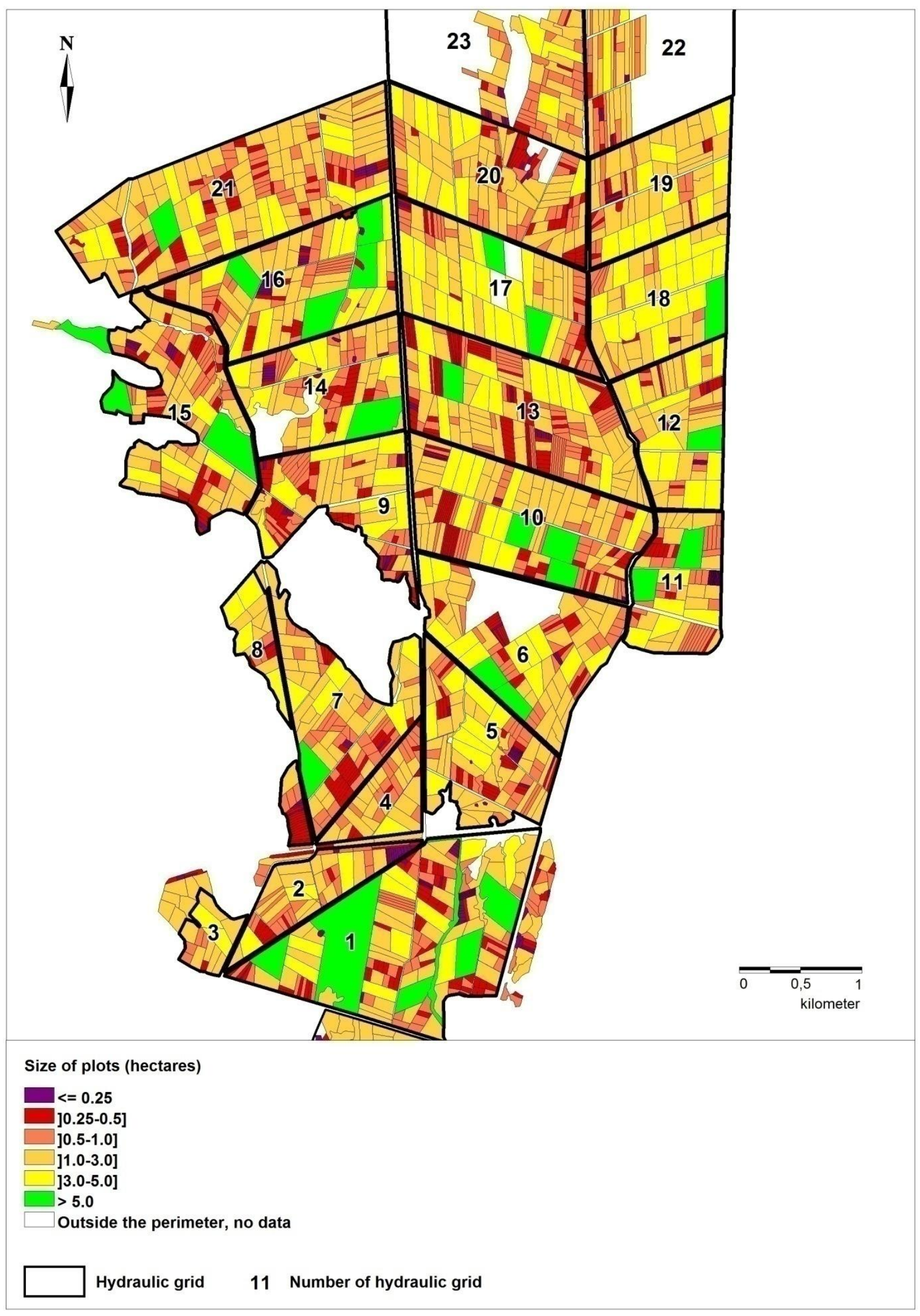

Figure 6. Plot layout of PC15 in 2008 (Data: BVLac). 


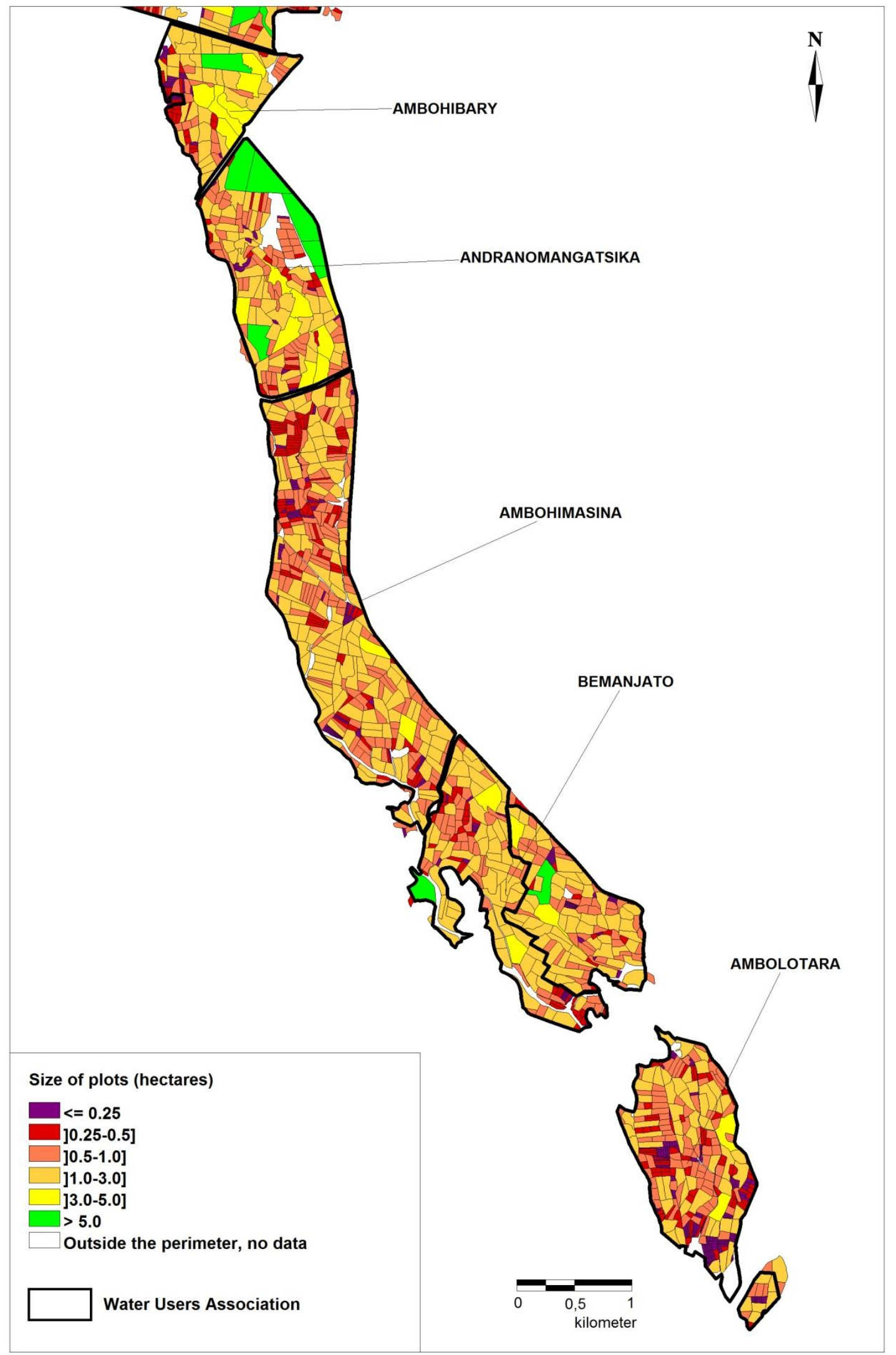

Figure 7. Plot layout of Marianina Valley in 2008 (Data: BVLac). 


\subsubsection{Changes in the size of holdings from 1970 to the present day: marked disparities between Marianina Valley and PC15.}

The area of holdings also tends to change, simultaneously with fragmentation. Small holdings are the first to be affected. Conversely, at least in Marianina Valley, large holdings conserve a degree of inertia and pre-eminence.

First of all, the average size of small holdings decreased from 2000 to 2012 (Figure 8). In PC15, the area covered by small holdings of 1 ha or less doubled during the period in question and formed a third of the total area in 2012, with accentuated pressure in the upstream part. The trend has been the same in the Marianina Valley, but with faster development of micro-holdings ( 0.5 ha and less) that formed $5 \%$ in 2000 but reached $13 \%$ in 2012, with their number increasing mainly in the upstream part of the valley. These features lead to deducing that fragmentation is certainly the direct consequence of the decrease in the average size of holdings. 


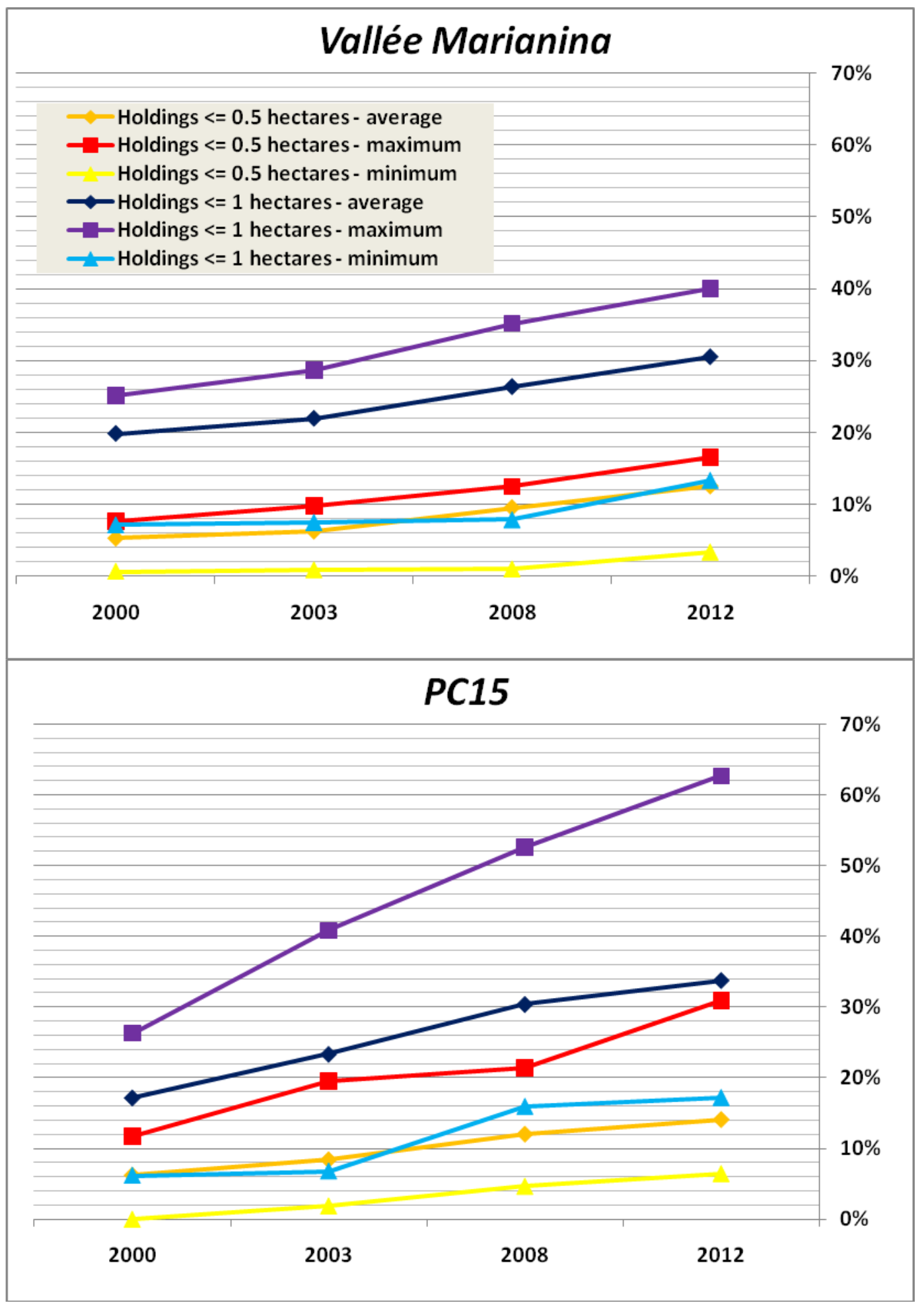

Figure 8. Proportion of the area devoted to small holdings from 2000 to 2012 -average and the extreme values in a grid or for an AUE in PC15 and the Marianina Valley (Data: FAUR).

Secondly, the increase in the number of micro-holdings contrasts with the maintaining of the largest ones, mainly in the Marianina Valley. Inequality in landholding 
between large landowners and small operators (small owner farmers or landless sharecroppers) is therefore increasingly marked. Figure 9 highlights the significant decrease in the area of large and medium-sized holdings in PC15 and, in contrast, the very measured decrease in the Marianina Valley.

In PC15, the decrease in medium-sized holdings (3 ha and more) was already strongly marked from 1970 to 2000 (100\% to $66 \%$ of the area) and accelerated exponentially from 2000 to 2012 (when these holdings formed only 38\% of the area). Larger holdings (5 ha or more) displayed a similar pattern, covering $22 \%$ of the area in 1970 and $15 \%$ in 2000 before plunging to less than $10 \%$ in 2012 . Although very large holdings (10 ha and more) remained practically intact until the beginning of the 2000s, they are now being broken up: they covered only $2.5 \%$ of the area in 2012 . Here, the holding owned by the bishopric of Ambatondrazaka is a surprising exception in PC15. A single lot united in a single plot, it has consisted of 35 ha of rice fields in grid 1 ever since land consolidation; it appears very clearly in figures 3 and 6.

The situation is very different in the Marianina Valley with inequality as regards access to land and, as a result, the 'untouchability' of the largest holdings. Dominated by the opposition between large and small holdings, the Marianina Valley has-historically-few holdings of intermediate size, unlike PC15 where the holdings have been of average size in the past. Holdings of 3 to 5 ha covered only 10\% of the area in 2012. Large and very large holdings are much more frequently seen in the valley than in PC15 and, surprising, they hardly decreased during the period examined. Holdings of 5 ha or more covered $24 \%$ of the area in 2000 and $22 \%$ in 2012 and holdings of 10 ha and more remained completely stable at 18\% from 2000 to 2008. The decrease observed from 2008 to 2012 (from 18\% to 11\%) results mainly from the division by inheritance of the 48-ha holding of Jacquis R. into six 8-ha holdings within the framework of the association Ambohimasina. Large holdings are concentrated in the downstream part of the valley and especially in Andranomangatsiaka. Here, the large holdings were originally colonial concessions and have now become undivided holdings belonging to all the inheritors of the initial purchase and management is handled by two or three of their representatives. The latter pay an annual lump sum tribute to the rest of the family, who live in Antananarivo or abroad. These large holdings give 
evidence of the rights traditionally recognized to the descendants of first comers (Evers, 2006, 2005).

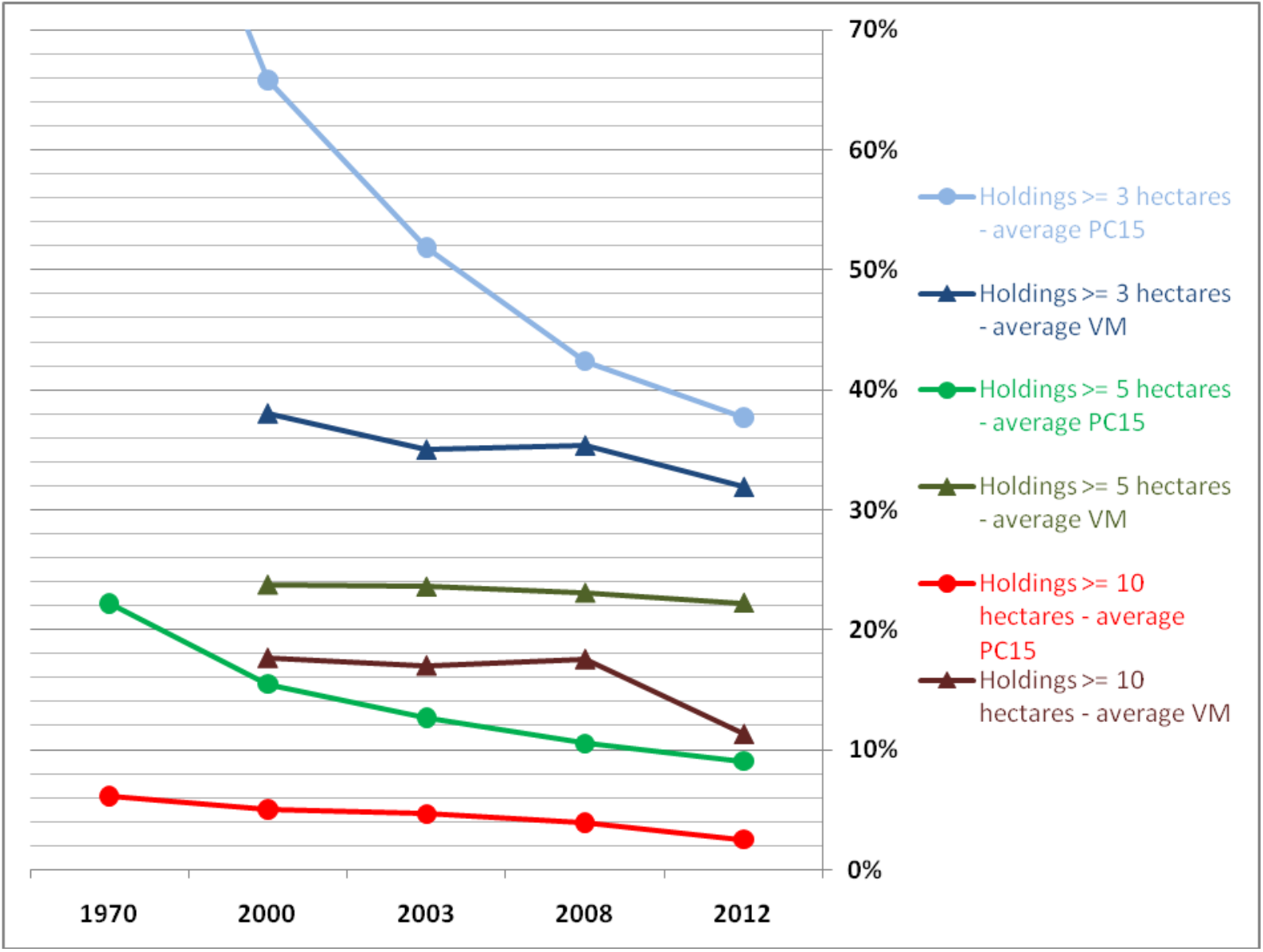

Figure 9. Proportion of the area occupied by large and medium-sized holdings from 1970 to 2012: average for PC15 and the Marianina Valley (Data: FAUR).

\subsubsection{Local, regional, and national causes for land fragmentation and holding size reduction}

Local explanations for land fragmentation, with its implications regarding holding average size, are put into perspective with what is already known on regional and national scales.

On a local scale, PC15 and Marianina Valley benefit from one of the best irrigation systems in lake Alaotra region, leading to paddy yields superior to 4 tons per hectare (at a national level, yields are about 2.5 tons per hectare)(Fujiki, 2013). The perimeter appears then attractive to migrants. This phenomenon is aggravated by the practice of inheritance in 
equal shares, customary among the farmers in the region (Brochoire, 2009) and enticed by the 1968 law on inheritance (USAID, 2010). Only 4\% of the owners in PC15 are the original owners who experienced land consolidation (Ratsimba, 2007), while legatees-sometimes fourth generation-form $75 \%$ of owners in PC15. This practice thus leads to the partitioning of the inherited land.

Regarding Marianina Valley in particular, other reasons may explain the accelerated fragmentation recently observed. It is due to the incorporation of the valley in the irrigated perimeter (creation of the Canal Principal de Rive Gauche - CPRG in 1993), with two main consequences. First, it increased the attractiveness of the valley and thus accelerated fragmentation that was already strongly marked for historical reasons (no consolidation and dominance of the Sihanaka agrarian structure). Second, ricecroppers were asked to regroup their lands with one another by the AUE - a minimum theoretical threshold of 2 hectares for each plot was required if a ricecropper wanted to be connected to the irrigation network, and admitted into the federation. Once the ricecroppers had their lands connected, they came back to the original situation - therefore, this fictitious land consolidation did not last long, explaining why fragmentation is even more acute in Marianina Valley than in PC15.

Those local factors are aggravated by the demographic pressure. On a regional and national scale, an intense population growth leads to a strong pressure on land, as Madagascar remains a rural country $-67 \%$ of the population is currently living in the countryside, and only one tenth of incoming working population in the decade 2010 will be absorbed by jobs in urban areas according to Dabat (2008). Between 1993 and 2011, annual growth of population reached 3.9\% in Madagascar and 3.3\% in the Alaotra-Mangoro region. Between the two census made by the Malagasy Ministry of Agriculture, Fisheries and Cattles, in 1985 and 2005, there was a decrease of available area cultivated per inhabitant, from 0.21 ha to 0.16 ha (here, only farming population is considered). Mean holding size decreased in the mean time from 1.2 ha to 0.87 ha on a national scale. Average holding size in the Alaotra-Mangoro region though remains a bit larger, with 1.10 ha available per inhabitant in 2005 , so that farming population growth and land fragmentation potential are even higher. 
In conclusion, there is a trend for the fragmentation of plots and a decrease in the size of holdings in the perimeter PC15-Valley Marianina, which echoes the trends observed on a regional and a national level. A distinction may be drawn nevertheless between PC15, where both large and small holdings are fragmented, and the Marianina Valley where inequality in access to land is acute, with the cohabitation of large, permanent holdings and micro-holdings that are below the viability threshold. However, general fragmentation dynamics hides other shorter-lived but symbolically important phenomena whose long-term sociological and political implications are still difficult to evaluate. This concerns in particular the problem of land grabbing by certain landowners.

\subsection{The multiplicity of landholding strategies at plot scale: a case study for a hydraulic grid (grid 21)}

The analysis below for grid 21, a large hydraulic grid in the downstream part of PC15, is aimed firstly at identifying the land acquisition strategies used by certain large landowners and secondly at drawing up a typology of lots' evolutions.

\subsubsection{The territorial strategies of large landowners: conservation of a landholding heritage and purchase of land}

In PC15, against the general trend for a reduction in the size of holdings, middle class urban newcomers (from outside the perimeter) and large landowners are succeeding in purchasing land to increase the size of their holdings. However, the land grabbing dynamics that can be seen in the perimeter are of local-scale. They do not involve large scale acquisitions by foreign agro-business investment, like Daewoo's cancelled project aiming at purchasing 1,300,000 ha of land (Burnod et al., 2013; Evers et al., 2011). They do not involve either environmentalists' pressures as observed otherwise in Madagascar (Seagle, 2012), even though PC15 is included into the lake Alaotra area protected by the Ramsar convention.

It is to be noted here that the lake Alaotra area is notable for the extent of land market activity. Nationally only $13 \%$ of lowland plots (mostly paddy fields) in rural areas are purchased, against $40 \%$ in the lake Alaotra region (Jacoby, 2007). PC15 appears to be in between (Brochoire, 2009), with a land market a bit less open than in the rest of the area due to the strong pressure on land and the number of titled properties - the latter indeed 
are less subject to sales, according to Jacoby (2007). Sales mainly concern the southern part of the perimeter where there is slightly less saturation and less property titling.

Purchasers in PC15 may be native from the region or be migrants coming from the national capital Antananarivo or from Antsirabe. The newcomers settle in lake Alaotra region to make their fortune with a start-up capital - they are not strictly ricegrowers but also have other complementary activities such as transport business or large dairy cattle breeding. Purchasers have two main buying strategies. First, they may use the 'vary maitso' (green rice system). This consists of lending money to rice growers in difficulty between harvests and, after the harvest, taking repayment in paddy rice at a third of the market price. They use this system of usury to build up capital that they invest in land. These buyers concentrate on small ricegrowers who are in debt and who prefer to sell their assets rather than be liable to seizure. Those small ricegrowers keep the remaining proceeds of the sale to buy cheaper land downstream of the perimeter near the marshes. A second buying strategy aims at leasing for several years a land from a small owner in financial difficulty. After several years of renewable leasing (or sharecropping) agreements, the owner generally decides to sale its land to its tenant. This is an example of reverse tenancy, when the landlord appears to be poorer than its tenant. This trend has already been observed in lake Alaotra region by Bellemare (2009).

Examination of the histories of the ten largest landowners currently established in grid 21 (summarised in Table 3) highlights these purchase strategies. In addition, the table shows the history of five other ricegrowers outside grid 21; one of them (Rak.) own the largest lot in grid 15, as can be seen clearly in figure 6. Study of the ten owners in grid 21 show their specific features and also echo the overall dynamics described above, providing a key to understanding them:

(1) Whereas the overall area of their holdings in PC15 as a whole tended to grow, increasing from an average of 5.2 ha in 2000 to 7.4 ha in 2012 (Table 3), the number of lots occupied by these owners increased from an average of 1.9 to 3.9 during the same period. In fact these growing estates are scattered and, seemingly paradoxically, contribute to fragmentation. This trend seen in PC15 contrasts with that observed in the Marianina Valley where block holdings that 
were former colonial concessions are dominant. Indeed, the spatial inertia of large estates is comparatively smaller in PC15.

(2) Actively involved in ricegrowing in the perimeter, nine out of ten (the exception being Ral.) of these large landowners cultivate their rice fields on an owner occupancy basis. Three ricegrowers who are not from grid 21 (Jean R., JeanBaptiste R. and Albert R.) became incorporated in the grid initially as ordinary farmers before purchasing various plots in some of the most fragmented lots. The most recent purchasers favour owner occupancy in order to guarantee their land rights and to limit the risk of dubious advantages being taken by tenants. This is a serious risk in the Lake Alaotra region and may be a reason among others for the stabilisation of owner occupancy in PC15 during the last 15 years.

\begin{tabular}{|c|c|c|c|c|c|}
\hline & 1970 & 2000 & 2003 & 2008 & 2012 \\
\hline \multicolumn{6}{|l|}{ Large landowners in grid 21} \\
\hline $\begin{array}{l}\text { Average number of lots occupied by each } \\
\text { ricegrower }\end{array}$ & 1 & 1.9 & 2.8 & 3.6 & 3.9 \\
\hline Average area owned by each ricegrower (ha) & 4.75 & 5.17 & 6.36 & 6.98 & 7.43 \\
\hline \multicolumn{6}{|l|}{ Area of the holdings of each ricegrower (ha): } \\
\hline Raj. & 6.5 & 6 & 10 & 12.25 & 13.75 \\
\hline Jean $\mathrm{R}$. & & 8 & 8.5 & 7.25 & 10.25 \\
\hline Ral. & & 5 & 8.8 & 8.55 & 7.45 \\
\hline Ernest R. & & 6.5 & 6.5 & 7.75 & 7 \\
\hline Thomas R. & & 1 & 3 & 8.25 & 7 \\
\hline Bernadette R. & & 6.5 & 8.5 & 4 & 6.5 \\
\hline Flavien R. & & 6.55 & 5.3 & 6.55 & 6.25 \\
\hline Albert R. & 3 & 4 & 4.5 & 4.75 & 5.75 \\
\hline Jean Baptiste R. & & 4 & 4 & 5.5 & 5.5 \\
\hline Célestine R. & & 4.17 & 4.52 & 4.92 & 4.85 \\
\hline \multicolumn{6}{|l|}{$\begin{array}{l}\text { Other large landowners } \\
\text { (other than in grid 21) }\end{array}$} \\
\hline \multicolumn{6}{|l|}{ Area of the holding of each ricegrower (ha): } \\
\hline Rak. (strong presence in grid 15) & 13.5 & 16.17 & 14 & 14 & 13.75 \\
\hline Jules R. (grids 13 and 14) & & 5.85 & 7.25 & 11.5 & 12 \\
\hline Georges L. T. (grid 11) & & 0 & 7 & 11.5 & 11.5 \\
\hline Henri R. (grid 17) & & 5 & 9.15 & 10.5 & 10.5 \\
\hline Claire R. (grid 14) & & 12 & 12 & 12 & 10 \\
\hline
\end{tabular}

Table 3. Evolution of the holdings of 15 large ricegrowers in PC15 from 1970 to 2012 (Data: FAUR). 


\subsubsection{Typology of lots' trends}

Beyond the general trends already described for the perimeter, the evolution of plot layout involved many factors at lot scale. The lots in grid 21 were classified using a typology with two entries-cohesion of the lot and evolution of the ownership to illustrate plot dynamics and the distribution of holdings. Lot cohesion was evaluated for 2012 using two criteria: the presence of one or several owners in the lot and owner or non-owner occupancy. The five inventories available (1970, 2000, 2003, 2008 and 2012) showed holding dynamics and the frequency and nature of transfers in each lot, with distinction made between four possibilities: (1) no transfers (the owner has not changed since 1970), (2) rare changes of ownership (only one of the inventories available reports a transfer of ownership), (3) gradual or partial transfer of ownership of the lot by the original owner spread over several inventories, and (4) frequent changes in ownership (at least two of the five inventories report transfers of ownership).

Analysis of this typology is shown in synthesis form in Table 4 and figure 10 and reveals opposing trends within grid 21 . The main dynamics can be identified: avatars of the former 'SOMALAC model', seeming stable lots with several owners ('multiple holdings' lots) and finally 'precarious' holdings.

(1) The family farming 'SOMALAC model' based on the farming of an entire lot by a single owner-operator still has a degree of prevalence and concerns a fifth of the lots in all. In addition to the original owners-those who experienced the land consolidation of the 1960s (4 holdings out of 70)-it also included sole inheritors or former operators who have become owners of the lots.

(2) Stable lots with multiple owners form about half of the lots in grid 21. Here, distinction should be made between lots in which transfers of ownership are rare $(20 \%)$ and those in which transfers are gradual or partial (29\% of the lots). This category also includes both divisions of the lots by inheritance and transfers to former operators.

(3) Slightly less than a third of the lots display frequent transfers and these are considered here as representing a priori a certain precariousness in ownership. 
Transfers by purchase seem more frequent in this category, as do owners from towns. In grid 21 as a whole, owners include persons from town in nine lots and five of these are considered as being precarious. The owners are generally from Ambatondrazaka, except in one case where they are from the capital Antananarivo (lot 2147).

Finally, it is interesting to note that from the spatial point of view the most stable lots are close to canal 18, whereas the most precarious ones are adjacent to drain D8 (Figure 2). The rice fields closest to the irrigation canals are also those that receive more regular irrigation and so the yields are more stable, in contrast with the rice fields close to the drains (Fujiki, 2013). Land considered as being the least productive will thus be sold more readily. Technical disparities therefore appear to be a key factor in landholding inequality and the geographic distribution of such inequality.

\begin{tabular}{|c|c|c|c|c|c|}
\hline \multicolumn{2}{|c|}{ Lot cohesion (2012) } & \multicolumn{4}{|c|}{ Ownership dynamics $(1970,2000,2003,2008,2012)$} \\
\hline Ownership structure & $\begin{array}{l}\text { Main tenure } \\
\text { system }\end{array}$ & Original owner & $\begin{array}{c}\text { Stable ownership. } \\
\text { rare transfers }\end{array}$ & $\begin{array}{l}\text { Gradual or partial } \\
\text { land transfer }\end{array}$ & $\begin{array}{l}\text { Precariousness. } \\
\text { Frequent transfers }\end{array}$ \\
\hline \multirow{2}{*}{$\begin{array}{l}\text { Single or joint } \\
\text { ownership }\end{array}$} & Owner & $5.8 \%$ & $13.0 \%$ & - & $1.4 \%$ \\
\hline & Non-owner & $4.3 \%$ & $1.4 \%$ & - & $0.0 \%$ \\
\hline \multirow{2}{*}{ Multiple owners } & Owner & - & $8.7 \%$ & $17.4 \%$ & $17.4 \%$ \\
\hline & Non-owner & - & $11.6 \%$ & $11.6 \%$ & $7.2 \%$ \\
\hline
\end{tabular}

Table 4. Typology of landholding dynamics in grid 21: proportional distribution by lot as \% of the total (Data: FAUR).

To conclude, analysis of grid 21 shows the dynamics at the scale of PC15. Firstly, inequality is increasing between the great majority of ricegrowers whose holding size decreases from one generation to the next and, in the most extreme cases, from one poor season to another, and a few landowners who succeed in increasing their holdings by using an active land grabbing strategy. Secondly, although trends in land ownership transfer move overall towards the division of lots, they also and above all reveal the increasing instability weighing on the status of some landowners. 


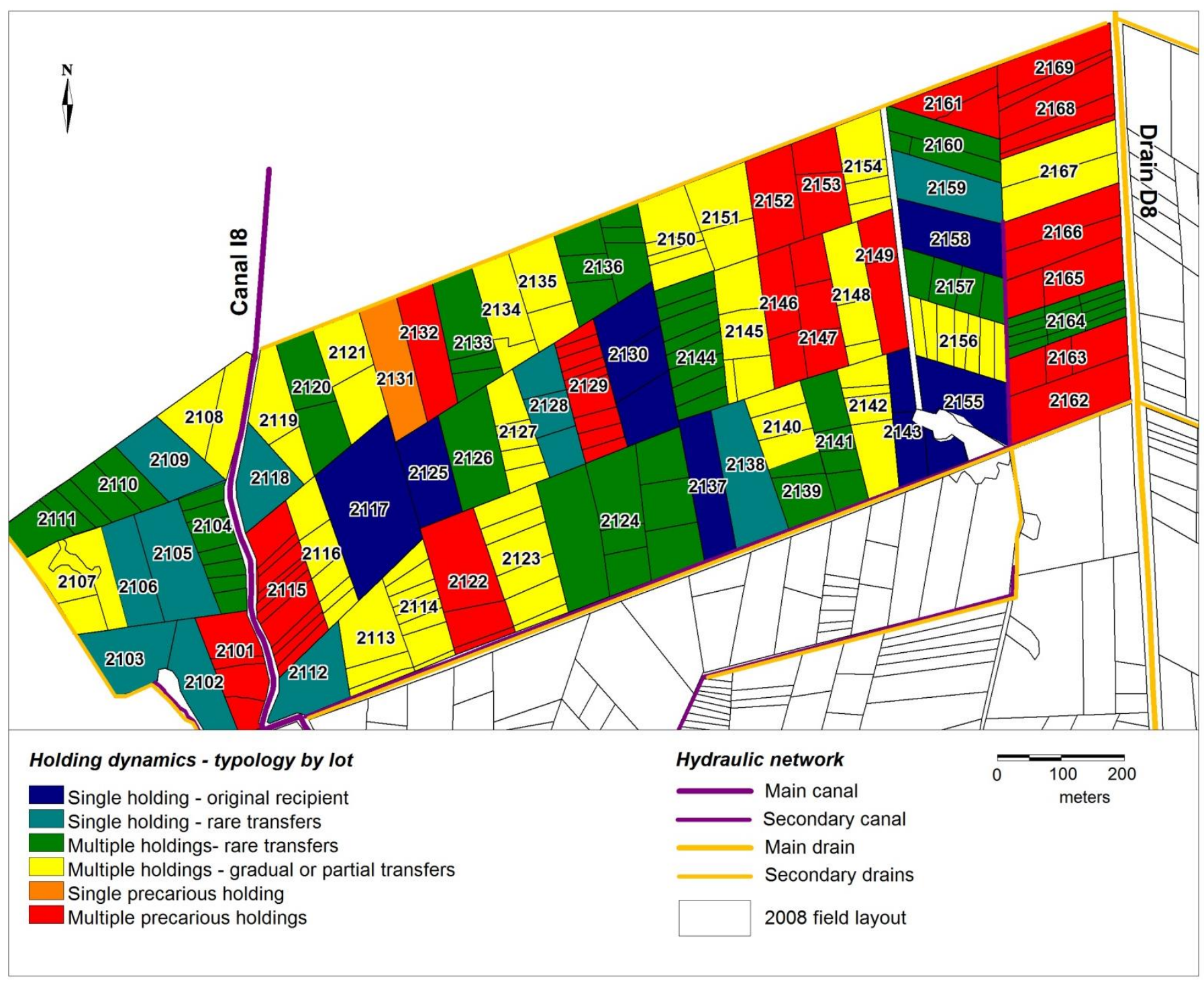

Figure 10. Cartography of landholding dynamics in grid 21: typology by lot (Data: FAUR).

\section{Conclusion}

Analysis of landholding dynamics at perimeter scale shows a trend for fragmentation and even hyper-fragmentation and a decrease in the size of holdings. However, there are strong disparities between the Marianina Valley, where large holdings with more than 5 hectares of land remain solidly established and maintain strong spatial cohesion, and PC15 which features the generalised division of holdings and a spatial dispersion of the largest.

The dynamics identified at the scale of the perimeter result in a host of situations at more local scales. The fragmentation of lots leads to instability of plot structure and also to greater agrarian precariousness and incertitude with regard to the status of owners and 
operators. Property transfers accelerate, as does the turnover in operators. Such instability is an opportunity for the wealthiest and most enterprising ricecroppers to implement land grabbing strategies by profiting from the fragility and difficulties of the majority. The landholding structure of PC15 has become flexible, featuring socio-spatial contradictions that become more marked every year, with exaggerated differences in wealth, dynamics and strategies. Far from being uniform, the perimeter area is made up of a patchwork of plots and holdings whose boundaries are changing more and more rapidly.

Consequences of land fragmentation and land grabbing may be observed on different levels. On a global level, fragmentation has got implications on population poverty, as already observed in other parts in the country. Poverty is indeed strongly correlated with holding and plot size, the poorest groups having the least lands (Stifel, 2010). If average holding size in Madagascar lies around 0.8 ha, poorest households only have an average of 0.5 ha against 1.8 ha for the wealthiest (USAID, 2010). Land fragmentation appears then fundamentally as a social problem, in the perimeter as in the rest of Madagascar.

On a local level, these landholding upsets have an impact on the collective management of the perimeter and especially the hydraulic aspect. As has already been noted, the lot is the basic unit of the land redevelopment performed in the 1960s, but it is also the hydraulic unit in PC15. The hydraulic network was originally laid out to supply entire lots. The more a lot is divided, the more complicated the water distribution to the various fields. Fragmentation implies technical problems (how can all the plots in the same lot be irrigated?) that result in informal solutions (small farm channels are dug, frequently wasteful cascade irrigation is used) and also problems of relations between people. Fragmentation results in competition for access to the irrigation network between the different operators in the same lot. Under such conditions, the common interest of the different ricecroppers risks to be called into question, putting finally at stake the sustainability of the network.

\section{Acknowledgements}

The authors thank the BVLac project team, and especially P. Grandjean and A. Rakotoarimanana, for giving us the opportunity to work on the PC15-Marianina Valley perimeter and to gather data. We also thank K. Yoshii of the Japan International Cooperation Agency (JICA) who kindly provided us with the inventory of PC23. Special thanks go to J. 
Ratsimba, socio-organiser at the FAUR, who gave us detailed informations on PC15 landholding structure. And we cannot forget the work made by all the technicians at the FAUR, who gathered and inventoried data, and without who this research could not have been completed. We are finally grateful to the reviewers for their helpful comments which enriched this paper.

\section{References}

Banque mondiale (World Bank). 1992. Projet d'intensification de la riziculture dans le bassin du lac Alaotra (crédit 1337-MAG). Madagascar. Rapport d'achèvement du projet. Division des Opérations-Agriculture. Département des Pays des Grands Lacs et de l'Océan Indien. Bureau Régional pour l'Afrique, 26pp.

Bellemare, M. 2013. The productivity impacts of formal and informal land rights: evidence from Madagascar. Land Economics 89, 272-290.

Bellemare, M. 2009. Sharecropping, Insecure Land Rights and Land Titling Policies: A Case Study of Lac Alaotra, Madagascar. Development Policy Review 27, 87-106.

Belloncle, G., Randriamananjara, D., Ratsimba, J. 2002. Une fédération des associations des usagers du réseau peut-elle gérer un grandd réseau hydroagricole ? Une étude de cas : la fédération PC15-Vallée Marianina au lac Alaotra. BERELAC, 63pp.

Blanc-Pamard, C. 1987. Autour du riz, le difficile face à face des paysans et de la SOMALAC dans la cuvette du lac Alaotra (Hautes terres centrales de Madagascar). Les Cahiers de la Recherche Développement 16, 67-81.

Blanc-Pamard, C., Cambrézy, L. 1995. Dynamique des systèmes agraires. Terre, terroir, territoire. Les tensions foncières. ORSTOM, Paris, 473pp.

Bouderbala, N., Cavérivière, M., Dérouiche, M., Mangatalle, D., Ratiaray, R. 1992. Les périmètres irrigués en droit comparé africain (Madagascar, Maroc, Niger, Sénégal, Tunisie). FAO, Rome, 147pp.

BRL-Madagascar. 2008. Appui à la gestion et l'entretien de réseau Vallée Marianina et PC15. Fédération des Association des Usagers de Réseau - Périmètres irrigués de la Vallée Marianina et du PC15, 29pp.

Brochoire, C. 2009. La sécurisation foncière dans un espace de fortes contraintes : l'exemple du périmètre irrigué PC15 au lac Alaotra, région Alaotra Mangoro, Madagascar. MSc Thesis in Politics, Université Paris I - Panthéon - Sorbonne, 99pp.

Broutin, C., Vogel, A., Rabarijaona, T., Rasamilala, A. 2011. Evaluation rétrospective du Projet de mise en valeur et de protection des bassins versants du lac Alaotra (BV LAC 1), Madagascar. Rapport provisoire. GRET, Paris, 30pp.

Burnod, P., Andrianirina Ratsialonana, R., Teyssier, A. 2013. Processus d'acquisition foncière à grande échelle à Madagascar: quelles régulations sur le terrain ? Cahiers Agricultures 22, 33-38.

Burnod, P., Andrianirina, N. Boue, C., Gubert, F., Rakototiana, N., Vaillant, J., Rabeantoandro, R., Ratovoarinony, R. 2012. Land Reform and Certification in Madagascar: Does 
Perception of Tenure Security Matter and Change? Presented at: Annual World Bank Conference on Land and Poverty, World Bank, Washington DC.

Carimentrand, A. 2011. Marchés agricoles à Madagascar. Contraintes et opportunités. Etude de cas : RIZ. Banque mondiale, CIRAD, 77pp.

Chaléard, J.-L., Mesclier, E., 2010. Introduction. Question foncière et dynamiques territoriales dans les pays du sud : nouveaux liens, nouvelles approches. Annales de Géographie 676, 587-596.

Charmes, J. 1973. De la rente foncière au capitalisme agraire. Transformation des structures sociales sur les périmètres d'Anony et Sahamaloto (SOMALAC). Université de Madagascar, Ecole nationale supérieure agronomique, 24pp.

Charmes, J. 1975. Métayage et capitalisme agraire sur les périmètres Nord de la SOMALAC. Cahiers de I'ORSTOM, série des sciences humaines, 12, 259-282.

Dabat, Marie-Hélène. 2008. L'agriculture Malgache Peut-Elle Sortir de L'impasse DémoÉconomique ? Autrepart 2/2008, 189-202.

De Janvry, A., Platteau, J.-P., Gordillo, G., Sadoulet, E. 2001. Access to land and land policy reforms. In: Access to Land Rural Poverty and Public Action. Oxford University Press, Oxford, pp. 1-26.

Devèze, J.-C., Jullien, J.-F., Papazian, V. 2003. Grands aménagements hydro-agricoles d'Afrique subsaharienne: poursuivre les évolutions institutionnelles. Afrique Contemporaine 205, 193-203.

Direction du développement et de la coopération technique (France). 2000. Problématique de trois systèmes irrigués en Afrique : fleuve Niger, fleuve Sénégal, lac Alaotra : bilan et évolutions institutionnelles. Ministère des affaires étrangères (France), 195pp.

Droy, I. 1994. Madagascar, de la gestion étatique à la gestion paysanne: le projet de réhabilitation des petits périmètres irrigués. Série de petits rapports sur le transfert de gérance des périmètres irrigués. International Irrigation Management Institute, $27 \mathrm{pp}$.

Droy, I. 1998. Que sont les greniers à riz devenus ? (Madagascar). Autrepart 7, 89-110.

Elden, S. 2010. Land, terrain, territory. Progress in Human Geography 34, 799-817.

Erismann, J. 2014. Développement hydro-agricole au Sud-est du lac Alaotra (Madagascar). Histoire, limites et perspectives de la maîtrise de l'eau. PhD Thesis in Geography, Université Jean Moulin Lyon III, 261pp.

Evers, S. 2013. Lex Loci Meets Lex Fori: Merging Customary Law and National Land Legislation in Madagascar. In: Contest for Land in Madagascar. Environment, Ancestors and Development, Brill Academic Publishers, Boston, pp. 119-140.

Evers, S., Burnod, P., Andrianirina Ratsialonana R, Teyssier, A. 2011. Foreign land acquisitions in Madagascar: competing jurisdictions of access claims. In: African Engagements. Africa Negotiating an Emerging Multipolar World. Brill Academic Publishers, Boston, pp. 110-132.

Evers, S., Haak, M., Lingnau, I., Lokhorst, N., Pronk, C. 2006. National legislation and local practices: competing jurisdictions in land management in Madagascar. Taloha 16-17. URL: http://www.taloha.info/document.php?id=336

Evers, S. 2006. Expropriated from the Hereafter: The Fate of the Landless in the Southern Highlands of Madagascar. Journal of Peasant Studies 33, 413-444.

Evers, S. 2005. Trumping the Ancestors: The Challenges of Implementing a Land Registration System in Madagascar. In: Competing Jurisdictions: Settling Land Claims in Africa, Brill Academic Publishers, Leiden, pp. 223-242. 
Ferry, L., Mietton, M., Robison, L., Erismann, J. 2009. Le lac Alaotra à Madagascar - Passé, Présent et Futur. Zeitschrift für Geomorphologie (ZfG) 53, 299-318.

Fujiki, K. 2013. Performance et viabilité d'un Grand Périmètre Irrigué : I'exemple du périmètre PC15-vallée Marianina (Région Alaotra-Mangoro, Madagascar). Contexte régional et national. MSc Thesis in Geography, Université Jean Moulin Lyon III, 107pp.

Fujiki, K., Mietton, M., Andrianalinoro, D, Rakotoarimanana, A. 2014. Les disparités de consommation de la ressource en eau au sein d'un périmètre rizicole irrigué (PC15Vallée Marianina. Région Alaotra-Mangoro. Madagascar.) Dynamiques environnementales 32, Presses Universitaires de Bordeaux. In press.

Funel, J.-M., Blanc-Pamard, C., Fontanel, P., Laucoin, G., Raymond, C. 1985. Conclusions de l'évaluation de la SOMALAC à Madagascar. Les Cahiers de la Recherche Développement 5, 11-17.

Garces-Restrepo, C., Vermillion, D., Muñoz, G. 2007. Irrigation management transfer. Worldwide efforts and results. FAO Water Reports 32. International Irrigation Management Institute, FAO, 62pp.

Garin, P., 1998. Dynamiques agraires autour de grands périmètres irrigués: le cas du lac Alaotra à Madagascar. PhD Thesis in Geography, Université Paris X - Nanterre, 380pp.

INSTAT. 2013. Population et démographie. URL : http://www.instat.mg/index.php? option=com_content $\&$ view=article\&id=33\&ltemid=56/ (14/08/2014).

Jacoby, H., Minten, B. 2007. Is Land Titling in Sub-Saharan Africa Cost-Effective? Evidence from Madagascar. The World Bank Economic Review 21, 461-485.

Jamin, J.-Y., Bouarfa, S., Poussin, J.-C., Garin, P. 2011. Les agricultures irriguées face à de nouveaux défis. Cahiers Agricultures 20, 10-15.

Japanese International Cooperation Agency (JICA), 2008. Etude du développement rural et de l'aménagement des bassins versants dans le sud-ouest de la région d'Alaotra. République de Madagascar. Rapport final. Project for Rice Productivity Improvement in Central Highland in Madagascar.

King, R., Burton, S. 1982. Land fragmentation: notes on fundamental rural spatial problem. Progress in Human Geography 6, 475-494.

Lapierre, J.-W. 1964. Les transformations de la société rurale dans la région du lac Alaotra. Civilisation Malgache 1, 203-224.

Lavigne Delville, P. 1998. Sécurité foncière et intensification. In: Quelles Politiques Foncières Pour l'Afrique Rurale ? Réconcilier Pratiques, Légitimité et Légalité. Editions Karthala, Coopération française, Paris, pp. 264-288.

Le Roy, E., Karsenty, A., Bertrand, A., 1996. La sécurisation foncière en Afrique. Pour une gestion viable des ressources renouvelables, Editions Karthala, Paris, 388pp.

Louzoun, G. 1967. Le remembrement au lac Alaotra. Terre Malgache - Tany Malagasy june 1967, 101-128.

Manjunatha, A.V., Anik, A.R., Speelman, S., Nuppenau, E.A. 2013. Impact of land fragmentation, farm size, land ownership and crop diversity on profit and efficiency of irrigated farms in India. Land Use Policy 31, 397-405.

Ministère de l'Agriculture, de l'Elevage et de la Pêche (MAEP). 2007. Recensement de L'agriculture. Campagne Agricole 2004-2005. Antananarivo.

Moine, A. 2006. Le territoire comme un système complexe: un concept opératoire pour l'aménagement et la géographie. Espace Géographique 35, 115-132.

Muttenzer, F. 2010. Politiques Foncières et Pluralisme Juridique À Madagascar. Taloha 19. URL: http://www.taloha.info/document.php?id=755. 
Niroula, G.S., Thapa, G.B. 2005. Impacts and causes of land fragmentation, and lessons learned from land consolidation in South Asia. Land Use Policy 22, 358-372.

Penot, E., Dabat, M.-H., Rakotoarimanana, A., Grandjean, P. 2014. L'évolution Des Pratiques Agricoles Au Lac Alaotra À Madagascar. Une Approche Par Les Temporalités. Biotechnologie, Agronomie, Société et Environnement 18, 329-338.

Perry, C., Steduto, P., Allen, R., Burt, C. 2009. Increasing productivity in irrigated agriculture: Agronomic constraints and hydrological realities. Agricultural Water Management 96, 1517-1524.

Rakoto Ramiarantsoa, H. 1985. Développement à contre-sens: un aménagement hydroagricole qui n'a pas donné les résultats escomptés. In: Les politiques de l'eau en Afrique : développement agricole et participation paysanne. Economica, Paris, 409420.

Ratsimba, J., 2007. Etude monographique et analyse des débiteurs de la redevance d'eau, campagne 2006-2007, périmètre PC15. BERELAC, BVLac Project, 7pp.

Raunet, M. 1984. Le milieu physique: aptitudes à la mise en valeur agricole. Système et structure. Région du lac Alaotra, Madagascar. Institut de Recherches Agronomiques Tropicales, Montpellier, 226pp.

Rochegude, A. 2012. La pérennisation du dispositif de gestion foncière décentralisée dans I'Alaotra. Mission de suivi institutionnel et juridique (09-18 janvier 2012). BVLac Project, 24pp.

Sack, R.-D. 1997. Homo Geographicus. The Johns Hopkins University Press, Baltimore, London, 304pp.

Seagle, C. 2012. Inverting the impacts: mining, conservation and sustainability claims near the Rio Tinto/QMM ilmenite mine in Fort Dauphin, Southeast Madagascar. Journal of Peasant Studies 39, 447-477.

Société Centrale pour l'Equipement du Territoire (SCET - Madagascar), 1965. Lac Alaotra. Etude des périmètres. PC15 et vallée de la Sasomanga. Ministère d’Etat chargé de l'agriculture, de l'expansion rurale et du ravitaillement (Madagascar), 212pp.

SOGREAH, SOMEAH, 1985. Etude hydrologique des périmètres de : Andranobe, Sahamaloto, PC23, PC15. Lac Alaotra. Ministère de la Production agricole et de la réforme agraire (Madagascar), SOMALAC, 36pp.

Stifel, D., Forster, F., Barrett, C. 2010. The Evolution of Groupwise Poverty in Madagascar, 1999-2005. Journal of African Economies 19, 559-604.

Teyssier, A., 1994. Contrôle de l'espace et développement rural dans l'Ouest Alaotra. De l'analyse d'un système agraire à un projet de gestion de l'espace rural (Bassinsversants de I'Imamba et de I'Ivakaka, lac Alaotra, Madagascar.) PhD Thesis in Geography. Université Paris I - Panthéon - Sorbonne, 472pp.

Teyssier, A., Raharison, H., Ravelomanantsoa, Z. 2008. La Réforme Foncière de Madagascar Ou Le Pari de La Compétence Locale. In : Population Rurale et Enjeux Fonciers À Madagascar. Editions Karthala, CITE, Paris, pp. 19-33.

Teyssier, A., Ramarojohn, L., Andrianirina Ratsialonana, R., Razafindrakoto, Y. 2009. Décentralisation de la gestion des terres à Madagascar: processus, enjeux et perspectives d'une nouvelle politique foncière. In: Les Politiques de Reconnaissance Des Droits Fonciers. Du Cadre Légal Aux Pratiques Locales. Editions Karthala, IRD, Paris, pp. 273-297. 
Turral, H., 1995. Devolution of management in public irrigation systems: cost shedding, empowerment and performance. A review. Working Paper 80. Overseas Development Institute, London, 98pp.

Turral, H., Svendsen, M., Faures, J.-M. 2010. Investing in irrigation: Reviewing the past and looking to the future. Agricultural Water Management 97, 551-560.

USAID. 2010. Property rights and resource governance. Madagascar.

URL: http://usaidlandtenure.net/madagascar 